Article

\title{
Exploring Social Sustainability Handprint-Part 2: Sustainable Development and Sustainability
}

\author{
Roope Husgafvel
}

check for updates

Citation: Husgafvel, R. Exploring Social Sustainability Handprint-Part 2: Sustainable Development and Sustainability. Sustainability 2021, 13, 11051. https://doi.org/10.3390/ su131911051

Academic Editor: Giovanni De Feo

Received: 2 September 2021

Accepted: 30 September 2021

Published: 6 October 2021

Publisher's Note: MDPI stays neutral with regard to jurisdictional claims in published maps and institutional affiliations.

Copyright: (C) 2021 by the author. Licensee MDPI, Basel, Switzerland. This article is an open access article distributed under the terms and conditions of the Creative Commons Attribution (CC BY) license (https:// creativecommons.org/licenses/by/ $4.0 /)$.
Department of Bioproducts and Biosystems, Aalto University, FI-00076 Espoo, Finland; roope.husgafvel@aalto.fi

\begin{abstract}
Social sustainability is a major part of both sustainable development and sustainability including societal sustainability and overall promotion of more sustainable societies taking into account multiple social/society-environment relationships and interfaces. These contexts have a strong focus on both present and future generations, encompassing sustainable development of both people and the planet. Social sustainability handprints provide many opportunities to promote social sustainability management and assessment by organizations and people and to create changes and encourage actions that contribute to overall social and societal sustainability. This study applied qualitative approaches to explore social sustainability handprints from the perspectives of sustainable development, sustainability, social and societal sustainability and sustainability assessment and indicators. This study addressed a clear research gap and aimed at identifying key definitions, elements, approaches and development focus areas within these frameworks as well as at suggesting associated implications for social sustainability handprint development. The findings suggest that social sustainability handprints can be created through multiple actions, changes, innovations and impacts to promote social sustainability based on sustainable development, sustainability and social and societal sustainability. Various actors such as all types of organizations, individuals, groups and companies can implement these ways to create social sustainability handprints. In addition, there are multiple assessment approaches that can be applied to the assessment of social sustainability handprints such as sustainability management, assessment and indicators, encompassing multiple specific elements and approaches.
\end{abstract}

Keywords: social sustainability handprint; handprint; sustainable development; sustainability

\section{Introduction}

This study explores social sustainability handprint development in the way that it supports further development and application by all types of organizations or by people/individuals, e.g., to promote, manage, assess and create changes towards social and societal sustainability. The overall handprint concept and approach were presented by the Centre for Environment Education (CEE) in 2007 at UNESCO's 4th International Conference on Environmental Education and they were linked to themes such as the principles of sustainability, human rights, social justice and gender equality and the contribution of work and lifestyles to the well-being of all life [1]. The handprint is about (1) action towards sustainability including positive and tangible actions (local/global) towards future sustainability, (2) commitment to act for the common good, (3) care for the planet and all life forms and (4) collaboration to take action for safer and healthier communities [2]. In addition, handprints are about creating and moving towards sustainability, encompassing, for example, practical actions such as education for sustainable development, choosing durable and reusable products, use of renewable energy, planting more trees or investing in sustainability [3].

Handprints can promote sustainability through a focus on positive actions of organizations, individuals and corporations and be a measure for positive action, collaboration and networking to promote sustainability [4]. For example, the handprint concept could 
support addressing sustainability challenges and contribute to global sustainable development targets (e.g., Agenda 2030) [5]. Previous studies have acknowledged that handprints can (1) promote a systemic thinking approach to sustainability (in addition to a linear thinking perspective on sustainability management and assessment) and innovation in an interconnected world [6], (2) be used as a tool for measuring positive impact of actions to promote sustainable development and that they are about actions to improve the well-being of people or the sustainability or healing of the planet [4] and (3) support addressing global challenges and promote innovation and collaboration among multiple actors to create positive impacts to promote sustainable development [7].

Handprints can also (1) be promising tools to promote sustainability improvements including normative approaches (what should be done and not only what has been done) [8], (2) be used as a measure of action by individuals to support measurable change of behavior to promote sustainable development [9], (3) be regarded as positive ways to think about sustainability and to take appropriate action including handprint thinking (the good we do with unlimited potential) $[10,11],(4)$ encourage people to work for sustainable development [12] and structural changes to promote sustainable behavior by all people [13] and (5) contribute to the achievement of climate targets and advance the implementation of multiple practical measures to combat global warming [3].

Sustainable development (sustainable development refers to development that meets the needs of the present generation without compromising the ability of future generations to meet their own needs [14]) is a broad concept and a global development goal, encompassing multiple dimensions, elements and approaches. Sustainability science and research are closely connected to this overall framework in addition to the similarly broad and diverse framework of sustainability. Sustainable development, e.g., (1) needs to promote global trends that contribute to the sustainability transition [15], (2) should be considered as a decision-making strategy by all stakeholders (from local to global level) and the main decision-making challenges can be addressed through sustainability assessment and indicators [16] and (3) requires a new vision of empowered stewardship [17]. The transition towards a more sustainable relationship between the human species and its natural life support system is a major challenge for humanity [18].

Sustainability will increasingly challenge almost all aspects of socio-economic systems and it will require new knowledge and ways to both generate and evaluate it [19]. In addition, sustainability and global sustainability transformation require governance to implement sustainability in practice [20]. The achievement of a sustainable future requires taking care of all dimensions of sustainability and addressing all interlinked impacts on people and the environment [21] as well as a fundamental shift in the development paradigm including focus on enhanced human well-being and environmental resilience [22]. It has been noted that the social dimension plays a major role in sustainability assessment [23].

There are many future collective handprints that can be created based on joint efforts [3]. Previous studies have recognized that handprint approaches could be extended to the development of a sustainability handprint [5] and that they could contribute to the creation of a circular economy including focus on well-being and happiness [3]. In addition, there is a need for (1) research on the extension of the handprint approach to more holistic sustainability handprint (e.g., taking into account social, environmental and economic handprints of products) [24] and (2) approaches and indicator systems to address the contributions of businesses to the UN SDGs [25]. There are multiple handprint assessment approaches (with potential role to promote sustainability including various perspectives on the world) and more focus is needed on alternative handprint assessment approaches including incorporation of social science understanding of pathways and agency into assessments and methods, tools and data sources [8]. Modern companies can significantly benefit from the development of the sustainability handprint concept [26].

Previous studies have identified many challenges related to both sustainability and handprints, encompassing the integration of (1) sustainability science into sustainability assessment studies [27], (2) social aspects into decision processes due to the fact that social 
impacts play a major role in sustainability assessment [28] and (3) human needs (interlinked and -twined with other entities such as nature and resources), integrated earth system including its support to well-being and of impacts on human well-being (e.g., health and happiness) into sustainability assessments [29]. In addition, there are challenges related to the implementation of the sustainability concept by most organizations related to the determination and measurement of sustainability performance including selection of social criteria, stakeholder involvement and data availability [30] and to the development of an assessment approach to social sustainability of products and processes due to, e.g., high complexity of the social sustainability dimension, data availability, assessment method issues and acceptance of the approach by the public and the industry [31].

\section{Materials and Methods}

This study aimed at exploring, discovering, analyzing and synthetizing the implications of (1) sustainable development, (2) sustainability, (3) social sustainability and (4) societal sustainability definitions and elements for the creation and assessment of social sustainability handprints. In addition, it aimed at exploring, discovering, analyzing and synthetizing the implications of sustainability assessment and sustainability indicator approaches and development focus areas for the assessment of social sustainability handprints. This study, including the specific results sections, is structured based on these specific aims related to both creation and assessment of social sustainability handprints.

In the chosen approach, social sustainability is closely linked to societal sustainability including social/society-environment relationships and interfaces. Interrelationships between social and economic sustainability including social/society-economy relationships and interfaces were beyond the scope of this study. However, many related and intertwined social and societal contexts and aspects are addressed. The materials included scientific books and articles, research reports, online sources and other publications (searched form all major academic research databases) focusing on handprints, sustainable development, sustainability (including sustainability science and research), social sustainability, sustainability assessment and sustainability indicators. This study is accompanied by a previous study (Part (1) [32], which addressed social sustainability handprints in the contexts of handprint and life cycle thinking and approaches. Additionally, there is one simultaneous study [33] that explores social sustainability handprint development in the contexts of both sustainability science and the UN SDGs/Agenda 2030. A similar research approach that is described in this section was also applied in that study.

A qualitative research approach was applied including the application of the following elements [34]: (1) collection and analysis of qualitative information using textual materials, (2) inductive, deductive and abductive reasoning, (3) theory construction (e.g., to promote improvement and provide guidance), (4) organization and synthesis of information and content analysis, (5) a theoretical and conceptual framework that evolves and changes based on new insights and progress of the study, (6) category and pattern construction (e.g., interrelationships, influences and interaction) and (7) summative synthesis and statements (e.g., linkages). Open discovery and insight and new insights and understandings as well as description, analysis and interpretation were also major parts of the approach [34].

The chosen approach acknowledges that there are multiple and diverse approaches to social sustainability handprints including ways to create and assess them. This study links social sustainability handprints with the comprehensive frameworks of both sustainable development and sustainability including numerous sustainability assessment and indicator approaches. Handprint approaches can be, e.g., dynamic and qualitative including focus on actions (e.g., [2,9,11,12]) or static and quantitative [7]. Handprints can be about supporting sustainable development and creating sustainability [3]. Handprint approaches can encompass (1) the good we do with unlimited potential, (2) inspiring, educating and influencing approach, (3) individual and collective creation (at home/work), (4) keeping count of accomplishments, (5) entrepreneurism and (6) recovery, restoration and advocation of protection [11]. In addition, sustainability handprints are about approaches to encour- 
age people and individuals to work for sustainable development including joint effort to promote a transformation towards a sustainable society and to implement sustainability including focus on, e.g., participation and institutions [12]. Handprint assessments can focus on positive actions and changes (e.g., innovations and initiatives) by organizations, individuals and companies [7].

In addition, handprint approaches can be about (1) solving of societal and environmental challenges, (2) promoting positive changes (e.g., within product life cycles), (3) supporting a sustainability transformation of societies and businesses, (4) assessment of positive contributions to sustainable development (e.g., active contributions of organizations including stakeholder inclusion/education) [25]. In addition, previous research has acknowledged that multiple approaches can be applied to the creation, development and assessment of handprints such as (1) actions to promote sustainability and sustainable development [9], (2) positive/tangible local and global actions towards future sustainability, commitments to act for the common good, care for the planet and all life forms and collaboration to take action for safer and healthier communities [2], (3) positive sustainability contributions, actions and impacts [26], (4) sustainability improvements [8], (5) innovation and collaboration among multiple actors to promote sustainable development [7], (6) innovation in an interconnected world and systemic thinking approaches to sustainability including sustainability management and assessment [6], (7) addressing sustainability challenges and contributions to global sustainable development targets (e.g., Agenda 2030) [5] and (8) holistic approaches to sustainability [24]

In addition, social sustainability handprint approaches can be based on, e.g., sustainability management, assessment and indicators (e.g., sustainability indices/indicators [35-37]), sustainability science and research approaches and handprint and life cycle thinking and approaches. The chosen approach both builds on and further extends the foundation created by previous research to fully acknowledge the diversity and broadness of the overall social/societal sustainability (including social/society-environment relationships and interfaces), sustainable development, sustainability and sustainability assessment contexts. Therefore, sustainability handprints can be created through multiple ways including (1) innovations, changes, actions/activities, initiatives and positive impacts, (2) sustainability management and assessment (e.g., indicators, index/indices and metrics), (3) sustainability science and research approaches, (4) handprint and life cycle thinking and approaches, (5) leadership, informed decision making, governance, design, planning and sustainable engineering and (5) improvements and changes towards sustainability and sustainable development including, e.g., social/societal sustainability and social/society-environment relationships and interfaces. For the purposes of this study, the social sustainability handprint concept and approach can be presented in a simplified manner as follows:

Social sustainability handprint $=\left(\right.$ social sustainability $_{(\text {normal practice })}+$ social sustainability handprint $\left._{(\text {social sustainability })}\right)-$ social sustainability $_{(\text {normal practice })}$

where

Social sustainability(normal practice) refers to the normal social sustainability practices/performance level (that can be used, e.g., as a baseline level of social sustainability) associated with, e.g., an organization, company, society/societal actor, a group of people, individual(s), products/services/processes or an activity/activities based on social sustainability assessment based on, e.g., (1) sustainability science/research approaches, (2) sustainability management and assessment using indicators/index/indices and/or (3) handprint and life cycle thinking and approaches.

Social sustainability handprint (social sustainability) refers to, e.g., actions, innovations, changes, impacts and initiatives that result in the improvement of social sustainability practices/performance level associated with an organization, company, society/societal actor, a group of people, individual(s), products/services/processes or an activity/activities based on social sustainability assessment based on, e.g., (1) sustainability science/research approaches, (2) sustainability management and assessment using indicators/index/indices and/or (3) handprint and life cycle thinking and approaches. 


\section{Results and Discussion}

\subsection{Sustainable Development}

Sustainable development is about (1) the creation of conditions for long-term sustainability for present and future generations (e.g., the balance between social justice, environmental protection and economic development and integrated and cooperative solutions to evolving challenges [38], (2) a decision-making strategy by all stakeholders (from local to global level) including sustainability assessment and indicators to address decision-making challenges [16], (3) the promotion of global trends that contribute to the sustainability transition [15], (4) a new vision of empowered stewardship [17] and (5) a sustainable relationship between the human species and its natural life support system and transdisciplinary approaches [8]. Sustainable development can be defined (in addition to the social, environmental and economic pillars) based on what it specifically aims to achieve, how it is measured (including the role of indicators), values supporting or representing it and practice (e.g., goals, indicators and values) [39]. In addition, sustainable development encompasses objective and subjective dimensions of human well-being [18,40] considering the framework of quality of life [40].

Sustainable development is a global challenge within local diversity, capacity and contingency including intergenerational and international dimensions (acting here/now to ensure conditions for high/decent quality of life elsewhere/later) [40]. Additionally, It can be interpreted based on subjective and value-based elements (considering that numerous ideas, observations and concepts from multiple scientific disciplines have created sustainability science) and its important elements include quality of life including sustaining and developing qualities of life [40]. Common visions about the goals of sustainable development focus, e.g., on equitable improvements of human well-being within and across generations [41]. In addition, sustainable development is about (1) a human effort to make choices and institutions to ensure that the earth can support the continued presence of humans for the indefinite future and (2) a vision of how human society could develop sustainably with strong focus on social dimensions such as intergenerational equity [42].

These findings suggest that the creation of social sustainability handprints needs to focus on changes, actions, innovations and impacts that are based on (1) the creation of conditions for long-term social sustainability for present and future generations, (2) integrated and cooperative solutions to evolving social and societal sustainability challenges, (3) help to achieve the defined social sustainability goals, (4) values supporting or representing social sustainability and social sustainability practices (e.g., goals, indicators and values), (5) subjective and value-based elements, sustainability science and common visions about social and societal goals associated with sustainable development (e.g., equitable improvements of human well-being within and across generations), (6) transdisciplinary and future-oriented approaches and inclusion of all stakeholders, (8) the advancement of human well-being and quality of life including intergenerational and international dimensions, (9) building sustainable social/society-environment relationships and interfaces and (10) social sustainability management, assessment and indicators. The implications of sustainable development definitions and elements for the creation of social sustainability handprints are presented in Table 1. whereas the implications for the assessment of social sustainability handprints are presented in Table 2.

In addition, the principles of international sustainable development law include many important issues that should be taken into account in the creation of social sustainability handprints. These principles encompass the following: (1) the duty of states to ensure sustainable use of natural resources (including conservation and protection of the environment such as ecosystems), (2) the principle of equity and eradication of poverty (e.g., inter- and intragenerational equity, just distribution of resources and meeting the basic needs of the poor), (3) the principle of common but differentiated responsibility (e.g., different circumstances, ability to prevent, reduce and control the threat and provision of assistance), (4) the precautionary principle (e.g., precautionary approach to human health, ecosystems and natural resources), (5) the principle of public participation (e.g., people 
participate in decision-making processes that affect and impact their lives and well-being)) and access to information and justice, (6) the principle of good governance (e.g., rule of law, democracy, political accountability, responsiveness/flexibility of government, democratic/transparent decision-making procedures and institutional structures that promote consensus building, coherence, coordination and community interests) and (7) the principle of integration and interrelationship (e.g., interdependence of social, environmental, human rights and economic/financial aspects, integration at all levels of governance and integrated thinking) [38,43-46].

Table 1. Implications of sustainable development definitions and elements for the creation of social sustainability handprints.

\begin{tabular}{l} 
Sustainable Development Definitions and Elements \\
\hline $\begin{array}{l}\text { Promotion of human development and well-being while } \\
\text { protecting the life support systems of the earth [47] }\end{array}$ \\
\hline (1) normativity (societal and normative choices and social \\
constructions by people based on values), (2) equity (fairness \\
and justice including, e.g., inter- and intragenerational aspects), \\
(3) integration (whole system perspective and integration of all \\
goals) and (4) dynamism (process of sustainability-oriented \\
change) [20]
\end{tabular}

Ways to Create Social Sustainability Handprints

Changes, actions, innovations and impacts to promote (1) human development and well-being and (2) sustainable social/society-environment relationships and interfaces

Changes, actions, innovations and impacts to promote (1) normative (societal and normative choices and social constructions based on values) aspects, (2) inter- and intragenerational equity, fairness and justice, (3) whole system perspective including integration of all social and societal goals and (4) dynamic social sustainability-oriented change processes

(1) quality of life, (2) improvement of the lives of human beings,

(3) an open and dynamic concept that includes multiple intersection possibilities among political, environmental and socio-economic processes and (4) can be defined, measured and achieved in many ways [48]

(1) multifaceted and normative concept, (2) human welfare and its relationships with nature in a framework in which nature-society imbalances can influence social and economic balance, (3) societal decision and action standards (to achieve well-being and survival), (4) integration of social, ecological and economic dimensions and (5) holistic and integrated approaches (to ensure coordinated operations among the social, environmental and economic domains) [49]

Changes, actions, innovations and impacts to promote (1) quality of life and (2) improvement of the lives of humans considering open, dynamic and multiple intersections among political, environmental and socio-economic processes

Changes, actions, innovations and impacts to promote (1) multifaceted and normative aspects, (2) human welfare and its relationships with nature, (3) solutions to nature-society imbalances, (4) social and societal balance, (3) societal decision and action standards, (4) sustainable

social/society-environment relationships and interfaces, (5) holistic and integrated coordination of activities related to social, societal and environmental aspects

Definition based on (1) what it specifically aims to achieve, (2) how it is measured (including the role of indicators), (3) values supporting or representing it and (4) practice (e.g., goals, indicators and values) in addition to the social, environmental and economic pillars [39]

(1) variability based on values, priorities and needs and (2) the suitability of measures may depend on contexts [50]

\section{The implementation of goals requires focus on interlinkages across societal actors (civil society, local authorities, government agencies and private sector) and sectors and between countries with different income levels [51]}

Preservation and fostering of dynamic, adaptable, satisfying, resilient and durable socio-ecological systems from the family level to the global level [52]
Changes, actions, innovations and impacts to promote social and societal sustainability goals, values, practices and indicators

Changes, actions, innovations and impacts to promote multiple values and to address multiple priorities and needs covering various contexts and considering selection of measures based on the context

Changes, actions, innovations and impacts to promote interlinkages across societal actors (e.g., civil society, local authorities and private sector) and sectors and between countries with different income levels

Changes, actions, innovations and impacts to promote dynamic, adaptable, satisfying, resilient and durable social/society-environment relationships and interfaces (from the family level to the global level) 
Table 2. Implications of sustainable development definitions and elements for the assessment of social sustainability handprints.

Sustainable Development Definitions and Elements
The development of a human, social and economic system that
is capable of maintaining itself indefinitely in harmony with the
biophysical systems of the planet [53]

(1) integrated approaches and (2) a broad social front (to make sustainable development concrete and achievable) including responsibility for a sustainable future by various sections of society [54]
Social Sustainability Handprint Assessment Approaches

Integration of (1) human, social and societal systems and (2) social/society-environment relationships that are capable of maintaining themselves indefinitely in harmony with the biophysical systems of the planet into assessment, development of indicators and collection of information

Integration of (1) broad social fronts to make social and societal aspects of sustainable development concrete and achievable and (3) responsibility for a sustainable future by various sections of society into assessment, development of indicators and collection of information

(1) present and future generations and the capacity of the earth and its natural resources (in accordance with the WCED 1987 definition), (2) natural resources should be not depleted by a small group of people and (3) the present generation should not compromise the capacity of future generations for their own development through irreparable damage to the environment, human health or to the economy [55]

A concept that is based on international developments in the fields of environmental conservation, human rights and development [56]

(1) human rights and public participation, (2) environmental protection (3) sustainable use of natural resources, (4) integration and interrelatedness, (5) good governance, (6) time dimension (temporality, longevity and promptness) and (7) sound macro-economic development [57]

What is to be sustained: (1) community (groups, cultures and places), (2) nature (ecosystems, biodiversity and earth) and (3) life support (environment, ecosystem services and resources) [58]

What is to be developed: (1) society (institutions, social capital, states and regions), (2) people (equity, equal opportunity, education, child survival and life expectancy) and (3) economy (productive sectors, wealth and consumption) encompassing the links between these components and the vision about the future [58]

(1) equality and mutual dependence among generations, peoples and nations of the earth, (2) future-orientation, interdisciplinarity, learning, participation and adaptation for the development of necessary socio-cultural, natural and socio-economical environments for the well-being of both humans and nature and (3) wide-ranging social, environmental and economic issues (inter-reliant dimensions that must be approached within an integrated framework) [49]
Integration of (1) present and future generations, (2) carrying capacity of nature, (3) sustainable use of natural resources and (4) protection of human health and the environment into assessment, development of indicators and collection of information

Integration of international developments in the fields of human rights, environmental conservation and social and societal aspects of sustainable development into assessment, development of indicators and collection of information

Integration of (1) human rights, (2) public participation, (3) sustainable use of natural resources, (4) interrelatedness, (5) good governance and (6) time dimension (temporality, longevity and promptness) into assessment, development of indicators and collection of information

Integration of social and societal sustainability aspects to be sustained: (1) community (groups, cultures and places) and (2) social/society-environment relationships and interfaces (e.g., life support, ecosystem services, biodiversity and resources) into assessment, development of indicators and collection of information

Integration of social and societal sustainability aspects to be developed: (1) society (e.g., institutions and social capital), (2) people (equity, equal opportunity, education, child survival and life expectancy), (3) links between people and society and (4) future visions about social and societal aspects of sustainable development into assessment, development of indicators and collection of information

Integration of (1) equality and mutual dependence among generations, peoples and nations, (2) future-orientation, interdisciplinarity, learning, participation and adaptation for the development of social, societal and cultural environments and social/society-environment relationships and interfaces that are essential for the well-being of both humans and nature and (3) wide-ranging social and environmental issues (inter-reliant dimensions) into assessment, development of indicators and collection of information

The implications of the principles of international sustainable development law for the creation of social sustainability handprints include the need to focus on changes, actions, innovations and impacts that promote (1) social and societal aspects of sustainable use of natural resources including sustainable social/society-environment relationships and interfaces, (2) inter- and intragenerational equity, just distribution of resources, meeting the 
basic needs of the poor and eradication of poverty, (3) common but differentiated social and societal sustainability responsibilities and actions (e.g., due to different circumstances, contexts, conditions, skills and capabilities), (4) precautionary approaches to social and societal sustainability and to social/society-environment relationships and interfaces (e.g., all ecosystems and natural resources), (5) public participation (e.g., in decision-making processes that affect and the lives and well-being of people), (6) access to information and justice as major parts of social and societal sustainability, (7) good governance (e.g., community interests, institutional structures that promote consensus building and responsiveness and flexibility of government) and (8) integration at all levels, interrelationships and integrated thinking.

\subsection{Sustainability}

Sustainability is a broad and diverse concept encompassing multiple definitions and elements that have implications for the creation and assessment of social sustainability handprints. Sustainability is about normativity (societal and normative choices and social constructions by people based on values), equity (fairness and justice including inter- and intragenerational aspects), integration (whole system perspective and integration of all goals) and dynamism (process of sustainability-oriented change) [20]. The most important elements of sustainability goals vary across places, times and groups and (the adequacy of the resource base to support human well-being now and in the future is a central feature of sustainability) [41]. It has been noted that the UN SDGs provide a mechanism for the communication of themes to activate the social norms that can potentially promote societally beneficial practices [59] and that future orientation is essential for sustainability including all dimensions and measures to address all interlinked impacts on people and the environment [21]. Previous studies have recognized the following characteristics of sustainability:

- Important future issues encompass (1) extending the existing metrics to better integrate the contribution of all relevant natural and anthropogenic resources, (2) addressing connections within and across systems organization levels, (3) addressing intra- and intergenerational equity and (4) monitoring of capacities that are necessary for sustainable development (e.g., capacity to measure sustainable development, promote equity and design governance arrangements that support collective management of shared resources and promote equity) [41].

- Based on normative orientation towards sustainability justice (the synthesis of sustainability relationships such as intra- and intergenerational justice between humans and justice towards nature), comprehensive scope, continuance, threefold relationality (nature and present and future generations), uncertainty (especially about the environment and future including interactions between human and natural systems) and limits [60].

- A dynamic, open and an evolving idea that aims at encompassing multiple interdependence, independence and interpretation possibilities among various sectors, actions, contexts and stakeholders across time and space and a concept that engages with environmental, social and economic domains (key issue is intergenerational equity which refers to fairness across generations) [48].

These findings suggest that the creation of social sustainability handprints needs to focus on changes, actions, innovations and impacts that are based on (1) societal and normative choices, social norms and societally beneficial practices, (2) social construction of people, (3) values, (4) equity, fairness and sustainability justice including interand intragenerational aspects, (5) system level thinking and social sustainability-oriented change processes, (6) the UN SDGs, current and future human well-being and consideration of various places, times and groups, (7) multiple, new and emerging assessment and monitoring metrics and indicators, (8) sustainable social/society-environment relationships and interfaces and (9) interdependence and independence among various sectors, contexts and stakeholders across time and space. In addition, it is essential that the assess- 
ment of social sustainability handprints includes the application of extended assessment approaches and indicators that better integrate all relevant social and societal aspects (including social/society-environment relationships and interfaces), address new and emerging themes and are capable of assessing and measuring social and societal aspects of both sustainable development and sustainability.

Sustainability challenges are related to almost all aspects of socio-economic systems that require new knowledge and ways to generate and evaluate sustainability [19]. There are multiple definitions and conceptualizations of sustainability [50] and previous studies have recognized that sustainability is (1) a multi- and cross-disciplinary concept [59], (2) an integrative concept (the integration of ecological, social and economic considerations is the foundation of the sustainability concept) [61], (3) a result of interdependencies between societal, environmental, cultural and economic drivers including dilemmas, contradictions and technical problems [62] and (4) a people-centered and conservation-based concept (the development of the standard of human life by respecting the capacity of nature to provide life supporting resources and facilities) that aims at maintaining the environmental carrying capacity [49]. In addition, it has been noted that humanity has not gotten closer to global sustainability despite long-term efforts of sustainability science and associated policy and action programs [63]. Previous studies have also recognized the following characteristics of sustainability:

- It is based on the social, environmental and economic pillars of sustainability (in the broadest sense) and it encourages coordination between humans and social, environmental and economic pillars of sustainability through sustainability strategies [21].

- A fundamental shift in the development paradigm including focus on enhanced human well-being and environmental resilience [22].

- Governance is needed to implement sustainability in practice and to promote a global sustainability transformation [20].

- It is about a (1) communal system with social equity and understanding of relationship to address the pressures caused by disharmony in the society and (2) the achievement of a stable relationship between human activities and the environment to ensure that future generations can have a good quality of life [21].

- It aims at (1) ensuring that the earth can meet the material and energy needs to support complex systems (e.g., humanity) over the long-term including social dimensions, (2) supporting human society and (3) making the survival of civilized human existence on earth feasible [42].

These findings suggest that the assessment of social sustainability handprints needs to integrate (1) responses and solutions to and the identification and analysis of direct, indirect and underlying reasons for the failure to achieve global sustainability goals (e.g., through policies and actions), (2) new knowledge and way to assess social and societal sustainability, (3) transdisciplinary approaches, (4) diverse ways to define and conceptualize social and societal sustainability, (5) social/society-environment relationships and interfaces, (6) interdependencies between societal, cultural and environmental drivers, (7) the development of the standard of human life through maintaining the environmental carrying capacity and respecting the capacity of nature to provide life supporting resources and facilities, (8) human well-being, good quality of life, social equity, good governance and societal harmony into assessment, development of indicators and collection of information. Further implications of sustainability definitions and elements for the creation of social sustainability handprints are presented in Table 3, whereas the implications for the assessment of social sustainability handprints are presented in Table 4. 
Table 3. Implications of sustainability definitions and elements for the creation of social sustainability handprints.

\begin{tabular}{l} 
Sustainability Definitions and Elements \\
\hline A social choice about what to develop and what to sustain and for \\
how long (linked to the internationally negotiated consensus on \\
development and environment issues including the associated \\
priority human needs and life support system goals, targets and \\
indicators) [64]
\end{tabular}

(1) The biophysical conditions of equity, environment and economy [65] and (2) new future-oriented systems approaches (in science, policy making and practice) to transform the world including focus on societal/social practice transformation taking into account the dynamic and complex nature of systems [66]
Ways to Create Social Sustainability Handprints

Changes, actions, innovations and impacts based on (1) social and societal choices about what to develop and what to sustain and for how long and (2) internationally agreed priority social and societal sustainability goals, human needs and life support system goals, targets and indicators

Changes, actions, innovations and impacts based on (1) equity, (2) sustainable social/society-environment relationships and interfaces, (3) new future-oriented systems approaches and (4) social and societal practice transformations considering the dynamic and complex nature of systems

Changes, actions, innovations and impacts to promote (1) transformation towards sustainable long-term social/society-environment relationships and interfaces (e.g., ecosystem services), (2) sustainable human well-being) based on long-term and continuous assessment, innovation and learning and (3) responses and solutions to risks and threats related to society, human health and livelihoods (e.g., adverse changes in social/society-environment relationships and interfaces)

Changes, actions, innovations and impacts based on (1) social and societal sustainability goals and (2) human values, attitudes and behaviors needed to achieve a sustainability transition

Changes, actions, innovations and impacts to promote (1) organizational social and societal sustainability goals, (2) organizational processes including continuous learning, knowledge creation and innovation and (3) efforts at the organizational and human levels

Integrated approach based on (1) addressing overarching concern in terms of well-being, equity, community engagement and security, (2) governance and education focusing on local experiences and cooperative processes and (3) engaged governance that addresses multiple issues (at the same time) and challenges the multiple pillar approach (separation of social, environmental and economic dimensions of sustainability) [70]

Efforts to promote good governance through inclusion of sustainability into framework, process and practice including focus on (1) integrated vision of sustainability, (2) local contexts and ideas, (3) participation of citizens in decision making and (4) access to necessary resources in governance processes [70]

(1) An ethical challenge, (2) a process of dynamic balance, (3) a means to achieve goals for society in terms of human happiness or prosperity, fulfilment of human capacity or advance of civilization (defined in specific societies, cultures or spiritual traditions) and (4) social and economic dimensions relate to human society including its purpose [71]
Changes, actions, innovations and impacts to promote (1) well-being, equity and community engagement, (2) security, (3) education, (4) local experiences and cooperative processes and (5) engaged governance that addresses multiple issues at the same time

Changes, actions, innovations and impacts based on and to promote (1) good governance, (2) integration of social and societal sustainability into processes and practices, (3) integrated vision of social and societal sustainability, (4) the importance of local contexts and ideas, (5) participation of citizens in decision making and (6) access to necessary resources in governance processes

Changes, actions, innovations and impacts to promote (1) responses and solutions to ethical challenges, (2) inclusion of dynamic balances associated with social sustainability, (3) societal goals (e.g., human happiness, fulfilment of human capacity, advance of civilization and prosperity as defined in specific societies, cultures or spiritual traditions) and (4) sustainable relationship of the social dimension with human society including its purpose 
Table 3. Cont.

\begin{tabular}{|c|c|}
\hline Definitions and Elements & Ways to Create Social Sustainability Handprints \\
\hline $\begin{array}{l}\text { (1) A challenge to conventional thinking and practice, (2) long-and } \\
\text { short-term well-being, (3) comprehensive coverage of all main } \\
\text { decision making issues, (4) recognition of interdependencies and } \\
\text { links (especially between human and the biophysical foundations of } \\
\text { life), (5) embedded in a world of complexity and surprise } \\
\text { (precautionary approaches are necessary), (6) recognition of both } \\
\text { inviolable limits and endless opportunities for creative innovation, } \\
\text { (7) open-ended process (not a state), (8) intertwined means and } \\
\text { ends (culture and governance and ecology, society and economy) } \\
\text { and (9) universal and context dependent [72] }\end{array}$ & $\begin{array}{l}\text { Changes, actions, innovations and impacts to promote (1) } \\
\text { progress beyond conventional thinking and practices, (2) } \\
\text { long and short-term well-being, (3) comprehensive coverage } \\
\text { of all main decision making issues, (4) } \\
\text { social/society-environment relationships and interfaces, (5) } \\
\text { precautionary approaches, (6) unlimited opportunities for } \\
\text { creative innovations, (7) understanding of critical and } \\
\text { inviolable limits, (8) open-ended processes, (9) intertwined } \\
\text { means and ends (e.g., culture and governance and society } \\
\text { and ecology) and (10) universal and context dependent } \\
\text { approaches }\end{array}$ \\
\hline $\begin{array}{l}\text { Local and global sustainability challenges caused by } \\
\text { interdependencies between societal, environmental, cultural and } \\
\text { economic drivers that (1) lead to mutual and dynamic } \\
\text { reinforcement with causes and effects at many geographic and } \\
\text { temporal scales and (2) imply multiple conflicts of goals and } \\
\text { interests [73] }\end{array}$ & $\begin{array}{l}\text { Changes, actions, innovations and impacts to address (1) } \\
\text { local and global sustainability challenges, ( } 2) \\
\text { interdependencies between societal, environmental and } \\
\text { cultural drivers, (3) mutual and dynamic reinforcement } \\
\text { including causes and effects at many geographic and } \\
\text { temporal scales and (4) multiple conflicts of goals and } \\
\text { interests }\end{array}$ \\
\hline
\end{tabular}

Table 4. Implications of sustainability definitions and elements for the assessment of social sustainability handprints.

\begin{tabular}{|c|c|}
\hline Sustainability Definitions and Elements & Social Sustainability Handprint Assessment Approaches \\
\hline $\begin{array}{l}\text { (1) The UN SDGs as an essential framework for sustainability } \\
\text { science [62,74], (2) adequate institutional framework including } \\
\text { adequate interfaces between policy and science [75] and (3) the } \\
\text { UN SDGs as an opportunity to mainstream sustainability } \\
\text { science [76] }\end{array}$ & $\begin{array}{l}\text { Integration of (1) the UN SDGs, (2) sustainability science, (3) } \\
\text { adequate institutional frameworks, (4) adequate science-policy } \\
\text { interfaces, (4) mainstreaming of sustainability science through } \\
\text { the UN SDGs into assessment, development of indicators and } \\
\text { collection of information }\end{array}$ \\
\hline
\end{tabular}

(1) The interpretation of the ethical implications and ethics of the UN SDGs including human-nature relationship based on an integrated approach to biocentrism and anthropocentrism, continuous inspection of values and attitudes and more focus on nature as a value and source for experience (in contrast to traditional focus on nature as a resource for action and knowledge) [77] and (2) ethics as part of the key foundations including social, environmental and economic dimensions [78]

Global transition based on balancing of human needs (human progress and quality of life) with the ability of ecosystems to provide goods and services (ecosystem integrity) [79]

(1) Learning in a key role in transitions including the generation of new knowledge, insights and collaborative action [80], (2) sustainability problem, policy and political learning in policy communities [81] and (3) the essential role of governance (e.g., societal decision making and institutions) and politics in understanding and analyzing transformations [82]

(1) Learning in transitions including, e.g., organizational (management studies) and collaborative learning and social learning in natural resources management (complex system thinking) [83] and (2) learning by doing in transitions [84]

(1) Many dimensions including multiple environmental, social and economic aspects and (2) governance can be supported by focus on knowledge integration and multi-actor governance [85]
Integration of (1) ethical implications and ethics of the UN SDGs, (2) social/society-environment relationships and interfaces, (3) continuous inspection of values and attitudes, (4) nature as a value and source for experience and (5) ethics including its social and environmental dimensions into assessment, development of indicators and collection of information

Integration of global transition based on balancing of human needs, progress and quality of life with the ability of ecosystems to provide goods and services (ecosystem integrity) into assessment, development of indicators and collection of information

Integration of (1) learning, (2) the generation of new knowledge, insights and collaborative action, (3) transitions and transformations, (4) sustainability problem, policy and political learning in policy communities and (5) governance (e.g., societal decision making and institutions) and politics into assessment, development of indicators and collection of information

Integration of (1) learning in transitions (e.g., organizational), (2) management, (3) collaborative learning, (4) social learning (e.g., management of natural resources), (5) system thinking and (6) learning by doing in transitions into assessment, development of indicators and collection of information

Integration of (1) multiple social dimensions and aspects, (2) governance based on knowledge integration and (3) multi-actor governance into assessment, development of indicators and collection of information 
Table 4. Cont.

\begin{tabular}{ll}
\hline \multicolumn{1}{c}{ Sustainability Definitions and Elements } & Social Sustainability Handprint Assessment Approaches \\
\hline $\begin{array}{l}\text { Goal achievement based on both understanding and } \\
\text { management of unprecedented and interconnected challenges } \\
{[86]}\end{array}$ & $\begin{array}{l}\text { Integration of the achievement of goals based on understanding } \\
\text { and management of unprecedented and interconnected } \\
\text { challenges into assessment, development of indicators and } \\
\text { collection of information }\end{array}$ \\
\hline
\end{tabular}

(1) Critical understanding by society (that is lacking) about institutional arrangements (knowledge systems) can effectively address science and technology for sustainability and (2) Mobilization of science and technology based on knowledge systems that manage boundaries between knowledge/expertise and action/decision making including focus on high-quality information, effective linking of knowledge and action, learning from field experience and enhancement of institutional and human capacity [87]

Integration of (1) critical understanding by society about and institutional arrangements, (2) science and technology for social sustainability, (3) knowledge systems to manage boundaries between knowledge/expertise and action/decision making, (4) high-quality information, (5) effective linking of knowledge and action, (6) learning from field experience and (7) enhancement of institutional and human capacity into assessment, development of indicators and collection of information

(1) Integration of sustainability assessment into municipal policy-making and planning processes and (2) local-level and community-based approaches to sustainability assessment including development of sustainable development indicators and monitoring systems [88]

(1) Sustainability is about how communities envision and pursue natural and social well-being [89] and (2) urgent addressing of sustainability challenges by society and science (e.g., climate change, deforestation, land degradation and land use change) [90]

Integration of (1) municipal policy-making and planning processes, (2) local-level and community-based approaches and (3) development of indicators and monitoring systems for social and societal aspects of sustainable development into assessment, development of indicators and collection of information

Integration of (1) the ways in which communities envision and pursue social and natural well-being and (2) sustainability challenges (e.g., climate change and deforestation) into assessment, development of indicators and collection of information

(1) A set of socio-ecological criteria that guide human action, (2) a vision of humankind (realization takes place through joining of social and ecological objectives of a particular system), (3) an approach (including the incorporation of social and ecological variables into the study of, e.g., systems or their social or environmental performance) and (4) an object (e.g., study object of sustainability science) [91]
Integration of (1) criteria related to social/society-environment relationships and interfaces to guide human actions, (2) visions of humankind (e.g., joint social/societal and environmental/ecological objectives), (3) social/societal and environmental/aspects, variables and performance and (4) sustainability science into assessment, development of indicators and collection of information

\subsection{Social and Societal Sustainability}

\subsubsection{Social Sustainability}

Social sustainability provides the foundation for social sustainability handprints and it encompasses multiple definitions and elements that have implications in the creation and assessment of social sustainability handprints. Social sustainability is strongly linked to the overall frameworks of both sustainability and sustainable development. Previous studies have acknowledged that social sustainability is (1) a particular branch of sustainable development that addresses its social dimensions and implications (sustainable development originally included a clear social mandate) including its connections to broader bio-physical environmental and economic issues and challenges [92], (2) about the integration of sustainable development dimensions, the incorporation of inter- and intragenerational equity considerations and engagement of the public in the research process (when addressed from the sustainability perspective) [93], (3) both a normative and an analytical concept [94] and (4) essential for sustainability because its constituents and principles promote a more sustainable society and ensure environmental and economic sustainability and system level resilience to manage, e.g., changes [95]

In addition, social sustainability can be significantly promoted by the civil society [96] and it is recognized that social dimension is the most challenging pillar of sustainable development including its theoretical, analytical and practical foundations [48]. The main underlying themes of social sustainability can be assessed and monitored by using (social) sustainability assessment methods, tools and metrics including the development of new indicators to address the emerging themes [97]. A previous study has also recognized 
the following elements of social sustainability: (1) development social sustainability (e.g., meeting basic needs and intra- and intergenerational equity), (2) bridge social sustainability (changing behavior to meet bio-physical environmental goals) and (3) maintenance social sustainability (what can be sustained in social terms and ways of life to be maintained or improved) [92].

These findings suggest that the creation of social sustainability handprints needs to focus on changes, actions, innovations and impacts that are based on and promote (1) social goals, dimensions, implications and aspects of sustainable development including social/society-environment relationships and interfaces, (2) inter- and intragenerational equity, (3) public participation including the application of (social) sustainability research, (4) normative and analytical approaches to social sustainability (e.g., management and assessment), (5) sustainable societies, (6) system level resilience to manage social and societal changes, (7) the essential role of the civil society and (8) ways to meet basic needs, (9) behavior changes and (10) sustaining, maintaining, improving and developing essential aspects of social sustainability and associated ways of life. In addition, these findings suggest that the assessment of social sustainability handprints needs to integrate management, assessment and indicators covering all social sustainability themes and continuously emerging new themes including continuous development of new indicators into assessment, development of indicators and collection of information. Further implications of social sustainability definitions and elements for the creation of social sustainability handprints are presented in Table 5. Whereas the implications for the assessment of social sustainability handprints are presented in Table 6.

Table 5. Implications of social sustainability definitions and elements for the creation of social sustainability handprints.

Social Sustainability Definitions and Elements

Social sustainability refers to (1) a life-enhancing and positive condition within communities and (2) a process within communities that can achieve that condition [98]

\section{Ways to Create Social Sustainability Handprints}

Changes, actions, innovations and impacts to promote (1) life-enhancing and positive conditions and (2) processes within communities (that can promote and achieve social sustainability)

Changes, actions, innovations and impacts to promote (1) social justice, equity, infrastructure and capital and (2) engaged governance (e.g., participation and community engagement) and (3) social and community well-being, community and human-scale development and community capacity building including the inclusion of social sustainability research approaches

Changes, actions, innovations and impacts to promote (1) equity, (2) social justice, (3) human rights and gender issues, (4) basic needs (e.g., environmental health), (5) education and skills, (6) employment and (7) poverty gender issues, (5) education and skills, (6) employment and (7) poverty $[93,100]$

Emerging themes: (1) well-being, happiness and quality of life, (2) health and safety, (3) empowerment, participation and access, (4), social capital (e.g., knowledge and social norms of conduct), (5) social mixing and cohesion, (6) demographic change (e.g., mobility, migration and ageing) and (7) identity, sense of place and culture $[93,100]$

Relation to multiple spatial and functional levels including international, national or regional, city, community or neighborhood and household or business [101]

(1) Equitable access and (2) community sustainability as the main dimensions of (urban) social sustainability [102]
Changes, actions, innovations and impacts to promote (1) well-being, happiness and quality of life, (2) empowerment, participation and access, (3) health and safety (4), social capital (e.g., knowledge and social norms of conduct), (5) social mixing and cohesion, (6) demographic change (e.g., mobility, migration and ageing) and (7) identity, sense of place and culture

Changes, actions, innovations and impacts at multiple spatial and functional levels (e.g., international, national, regional, city, community, neighborhood, household and business)

Changes, actions, innovations and impacts to promote (1) community sustainability and (2) equitable access as the main dimensions of urban social sustainability 
Table 5. Cont.

\begin{tabular}{|c|c|}
\hline Elements & Social Sus \\
\hline $\begin{array}{l}\text { (1) Equity, (2) public awareness, (3) particip } \\
\text { cohesion as the overarching social concepts } \\
\text { sustainable development that can be extend } \\
\text { environmental, international and intergener } \\
\text { (sustainable development concept and polic } \\
\text { including the development of interpillar lin }\end{array}$ & $\begin{array}{l}\text { Changes, actions, innovations and impacts to promote (1) } \\
\text { equity, (2) public awareness, (3) participation and (4) social } \\
\text { cohesion as parts of the social and societal aspects of sustainable } \\
\text { development including their extension to include international } \\
\text { and intergenerational dimensions and } \\
\text { social/society-environment relationships and interfaces }\end{array}$ \\
\hline $\begin{array}{l}\text { ity meaning both (1) the } \\
\text { ell-being and health (now and in } \\
\text { tions that facilitate } \\
\text { ustainability (now and in the }\end{array}$ & $\begin{array}{l}\text { novations and impacts to promote (1) } \\
\text { e social well-being and health (now and in } \\
\text { ocial institutions to facilitate sustainable } \\
\text { onment relationships and interfaces (now }\end{array}$ \\
\hline $\begin{array}{l}\text { (1) The improvement of conditions for living peop } \\
\text { generations, (2) the quality of governance of the d } \\
\text { process, (3) substantive (social sustainability goals } \\
\text { goals of sustainable development to be achieved) } \\
\text { procedural (means to achieve the goals) aspects ar } \\
\text { integration of social and environmental aspects (e } \\
\text { management and policy) based on a long-term lea } \\
\text { and focus on procedural aspects of social sustaina } \\
\text { participation) [105] }\end{array}$ & $\begin{array}{l}\text { to promote (1) the } \\
\text { and future } \\
\text { f the development } \\
\text { cial goals of } \\
\text { e } \\
\text { nd interfaces (e.g., } \\
\text { rm learning } \\
\text { ustainability (e.g., }\end{array}$ \\
\hline $\begin{array}{l}\text { A social-en } \\
\text { participatio } \\
\text { cohesion di }\end{array}$ & $\begin{array}{l}\text { cts to promote (1) } \\
\text { relationships and } \\
\text { ) awareness for } \\
\text { nensions }\end{array}$ \\
\hline $\begin{array}{l}\text { (1) Social justice is the central part of the UN SDGs and it refers } \\
\text { to the creation of a society that is based on equality, human } \\
\text { rights and solidarity, (2) the importance of social inclusion and } \\
\text { gender equality, (3) policy making for the promotion of equity } \\
\text { (e.g., a universal approach to social policy and integration of } \\
\text { broader social protection systems including the application of } \\
\text { indicators, inclusive institutions, addressing discrimination and } \\
\text { continuous provision of data to ensure that no one is left } \\
\text { behind) [48] }\end{array}$ & $\begin{array}{l}\text { justice, (2) the creation of a society that is based on equality, } \\
\text { human rights and solidarity based on the UN SDGs, (3) social } \\
\text { inclusion and gender equality, (4) policy making for the } \\
\text { promotion of equity, (5) a universal approach to social policy, (6) } \\
\text { integration of broader social protection systems, (7) application } \\
\text { of social sustainability indicators, (8) inclusive institutions and } \\
\text { (9) addressing discrimination based on continuous provision of } \\
\text { information/data on social sustainability }\end{array}$ \\
\hline
\end{tabular}

Table 6. Implications of social sustainability definitions and elements for the assessment of social sustainability handprints.

\begin{tabular}{|c|c|}
\hline inability Definitions and Elements & ility Handprint Assessment Approaches \\
\hline $\begin{array}{l}\text { Interrelated and measurable social sustainability indicators that } \\
\text { also represent action to establish and implement social } \\
\text { sustainability: (1) equity of access to key services, (2) equity } \\
\text { between generations, (3) a system of transmitting awareness of } \\
\text { social sustainability across generations, (4) widespread political } \\
\text { participation of citizens, (5) valuation and protection of different } \\
\text { cultures and promotion and support of cultural integration (if } \\
\text { desirable by groups/individuals) within the system of cultural } \\
\text { relations, (6) mechanisms for a community to collectively } \\
\text { identify its strengths and needs and to fulfil its own needs } \\
\text { through community action and (7) mechanisms for political } \\
\text { advocacy to meet needs that cannot be met by community }\end{array}$ & $\begin{array}{l}\text { Integration of (1) equity of access to key services, (2) equity } \\
\text { between generations, (3) a system of transmitting awareness of } \\
\text { social sustainability across generations, (4) widespread political } \\
\text { participation of citizens, (5) valuation and protection of different } \\
\text { cultures and promotion and support of cultural integration (if } \\
\text { desirable by groups/individuals), (6) mechanisms for } \\
\text { communities to collectively identify their strengths and needs } \\
\text { and to fulfil their own needs through community action and (7) } \\
\text { mechanisms for political advocacy to meet needs that cannot be } \\
\text { met by community action into assessment, development of } \\
\text { indicators and collection of information }\end{array}$ \\
\hline $\begin{array}{l}\text { Operational-level approach based on actions in main thematic } \\
\text { areas covering the social realm of societies and individuals (e.g., } \\
\text { capacity building, skills development and environmental }\end{array}$ & $\begin{array}{l}\text { Integration of (1) operational-level approaches, (2) actions in } \\
\text { main thematic areas of social sustainability by societies and } \\
\text { individuals, (3) skills development, (4) capacity building and (5) } \\
\text { environmental inequalities into assessment, development of } \\
\text { indicators and collection of information }\end{array}$ \\
\hline
\end{tabular}


Table 6. Cont.

\begin{tabular}{l} 
Social Sustainability Definitions and Elements \\
\hline (1) Distinctive and stand-alone objective or social pillar of \\
sustainability (including, e.g., social sustainability indicators or \\
index), (2) a fully integrated, place-based and process-oriented \\
approach to sustainability, (3) a precondition and foundation for \\
environmental and economic sustainability, (4) a causal \\
mechanism for changes in environmental and economic \\
sustainability and (5) a constraint on environmental and \\
economic pillars of sustainability [106]
\end{tabular}

Interlinked with the other sustainability dimensions (impacted by any change) [107]

Social impacts of business organizations and activities are related to interactions with and impacts on organizational stakeholders such as employees including unions, suppliers/supply chain, communities and consumers [108]

(1) Socially sustainable actions and activities enhance the long-term well-being of social institutions and (2) the moral legitimacy of social sustainability is based on action/activities in the public interest (e.g., organization acting in the interest of society) [109]

Social capital (e.g., networks and norms) can be used to (1) assess social aspects of sustainability and (2) measure social sustainability with particular focus on measuring the social-environmental interface of communities and measuring and reporting community sustainability efforts [110]

(1) A quality of societies, (1) nature-society relationships mediated by work and relationships within society and (3) achieved if work and related institutional arrangement within a society satisfy a broad set of human needs and are shaped in a way that ensures long-term preservation of nature (including its reproductive capabilities) and fulfilment of normative claims of social justice, participation and human dignity [94]

(1) Health and safety of every social domain, (2) good quality of life, (3) impacts on local communities and (4) extra benefits to disadvantaged groups of society [21], (5) human well-being, (2) equity, (3) democratic government and governance and (4) democratic civil society [95]

(1) How individuals, communities and societies live with each other and how they set out to achieve the objectives of the chosen development models considering the physical boundaries of both specific places and the whole planet and (2) mix of social policy areas and principles including, e.g., well-being, quality of life, happiness, equity and health, participation, needs, social capital and the environment $[93,100]$.
Social Sustainability Handprint Assessment Approaches

Integration of (1) social sustainability objectives and (2) social aspects of sustainable development and sustainability, (3) social sustainability indicators and indexes, (4) fully integrated, place-based and process-oriented approaches to sustainability and (5) social/society-environment relationships and interfaces including changes and constraints into assessment, development of indicators and collection of information

Integration of interlinkages with and impacts of changes in environmental sustainability into assessment, development of indicators and collection of information

Integration of (1) social sustainability impacts of business organizations and activities, (2) interactions with and impacts on organizational stakeholders such as employees, unions, suppliers, supply chain, communities and consumers into assessment, development of indicators and collection of information

Integration of (1) socially sustainable actions and activities, (2) long-term well-being of social institutions and (3) moral legitimacy of social sustainability based on action and activities in the public interest (e.g., organizations that act in the interest of societies) into assessment, development of indicators and collection of information

Integration of (1) social capital (e.g., networks and norms), (2) social aspects of sustainability, (3) social-environmental interfaces of communities and (4) sustainability efforts by communities into assessment, development of indicators and collection of information

Integration of (1) qualities of societies, (2)

social/society-environment relationships and interfaces, (3) relationships within societies, (4) work and related institutional arrangements within societies, (5) a broad set of human needs, (6) long-term fulfilment of normative claims of social justice, (7) participation, (8) human dignity and (9) preservation of nature and its reproductive capabilities into assessment, development of indicators and collection of information

Integration of (1) good quality of life, (2) health and safety of all social domains, (3) impacts on local communities and (4) extra benefits to disadvantaged groups of society into assessment, development of indicators and collection of information

Integration of (1) human well-being, (2) equity, (3) democratic government and governance and (4) civil society into assessment, development of indicators and collection of information

Integration of (1) how individuals, communities and societies live with each other and how they specify the ways to achieve the chosen social sustainability objectives, (2) social/society-environment relationships and interfaces taking into account the physical boundaries of specific places and the whole planet and (3) a mix of social sustainability areas and principles including well-being, quality of life, happiness, equity and health, participation, needs and social capital into assessment, development of indicators and collection of information 


\subsubsection{Societal Sustainability}

Societal sustainability is a broad and diverse concept that encompasses multiple definitions, elements and approaches. This concept is also linked to the overall frameworks and both sustainability and sustainable development. Previous studies have recognized that (1) the achievement of socially sustainable societies is an iterative process that simultaneously requires definition of the meaning of the concept, ways to measure the outcomes of action and policy (to assess progress and make adjustments) and necessary conditions for pursuing social sustainability [96], (2) societies can promote a sustainability transition using sustainability indicators to establish or change direction, assess progress and to get warnings of unsustainability [47], (3) the promotion of a sustainable society requires focus on quality of life indicators and social diversity [107] and (4) societal sustainability includes human-ecological relations including establishment and maintenance of long-term integrity of socio-biophysical systems and protection of the life support functions that are essential for both human and ecological well-being [72]. In addition, previous studies have recognized the following important definitions and elements of societal sustainability:

- Societal sustainability is about (1) sustainability implications of social aspects (e.g., institutions, culture and politics) and their influence on the interaction of social and natural systems and (2) a systems perspective and approach that integrates social and natural systems encompassing consideration of social and environmental quality justice in particular social or economic fields [19].

- (1) Business organizations are societal institutions that should play a role in ensuring the long-term viability of a democratically governed society that is based on equality, justice and trust and supported by sustainable social, natural and economic systems and (2) organizational management needs to be held accountable by society (e.g., evaluation of outcomes based on criteria that reflect the norms and values of the society) including the use of resources [109].

- Understanding of the environmental dimension of sustainable development in the context of societal sustainability requires focus on, e.g., biodiversity (ecosystem, species and genetic diversity) and ecosystem services (things acquired by people from nature to support well-being) [48].

These findings suggest that the creation of social sustainability handprints needs to focus on changes, actions, innovations and impacts that promote (1) all aspects of societal sustainability, societal aspects of sustainable development and sustainable societies, (2) consensus- and capacity-building processes and approaches for societal sustainability, (3) the inclusion of multiple stakeholder communities, (4) social diversity and sustainability transitions, (5) sustainable social/society-environment relationships and interfaces (e.g., ecosystem services, biodiversity and life support functions), (6) human and ecological well-being and social and environmental justice, and (7) the contribution of business organizations (as societal institutions) to the long-term viability of a democratically governed society that is based on equality, justice and trust and supported by sustainable social and natural systems. Further implications of societal sustainability definitions and elements for the creation of social sustainability handprints are presented in Table 7.

Table 7. Implications of societal sustainability definitions and elements for the creation of social sustainability handprints.

\begin{tabular}{ll}
\hline \multicolumn{1}{c}{ Societal Sustainability Definitions and Elements } & \multicolumn{1}{c}{ Ways to Create Social Sustainability Handprints } \\
\hline $\begin{array}{l}\text { Consensus-building processes and approaches and associated } \\
\text { capacity-building taking into account that various stakeholder } \\
\text { communities can be used to support a sustainable society [111] }\end{array}$ & $\begin{array}{l}\text { Changes, actions, innovations and impacts to promote (1) } \\
\text { consensus- and capacity-building processes and approaches and } \\
\text { (2) the role of stakeholder communities in promoting more } \\
\text { sustainable societies }\end{array}$ \\
\hline $\begin{array}{l}\text { Sustainable society requires sustainability education including } \\
\text { focus on sustainability problems and approaches to address } \\
\text { them based on system thinking from a holistic perspective [112] }\end{array}$ & $\begin{array}{l}\text { Changes, actions, innovations and impacts to promote (1) } \\
\text { sustainability education, (2) responses and solutions to } \\
\text { sustainability problems and (3) holistic perspectives and system } \\
\text { thinking }\end{array}$ \\
\hline
\end{tabular}


Table 7. Cont.

\begin{tabular}{l} 
Societal Sustainability Definitions and Elements \\
\hline (1) Enhanced capacity to promote equity for sustainable \\
development and social sustainability (including empowerment \\
of actors in weaker positions), (2) equity/inequity as related to \\
fairness and justice (distribution of resources within and \\
between generations) and (3) equality in access to resources can \\
be influenced through policy (e.g., sustainability goals) [41]
\end{tabular}

(1) Public deliberation and participatory decision making on environmental problems by citizens and (2) protection of regional environments based on bottom-up type of governance [113]

Knowledge structuring (interdisciplinary research and transdisciplinary expertise) to create an interdisciplinary intellectual base, action-structuring (decomposition of actions, integration into new actions and promotion of collective actions) and knowledge accompanied by action to change a situation [114,115]

Identification of sustainability problems by public-policy makers based on (1) problem-structuring from a multidisciplinary viewpoint and (2) understanding of the multiple problem identification perceptions of participants with regard to the social/natural system [111]

(1) Interactions of society and nature in the Anthropocene System form a complex adaptive system that is globally interconnected and includes formative roles played by innovation, heterogeneity and nonlinear relationships, (2) the unpredictable nature of the dynamics of this system and (3) partial guidance is possible through appropriate interventions $[41,116]$

Contribution of biodiversity to societal well-being, human health and ecosystem services [117] and social systems that reflect the interaction between humans and the biological systems as an indicator of sustainability accomplishment including the maintenance and restoration of biodiversity in ecosystems (essential for sustainable ecology) [49]

(1) Integration of societal, environmental and industrial systems and (2) establishment of decision support systems that evaluate societal, environmental and economic impacts and address inputs from society and associated ethical considerations [118]

\section{Ways to Create Social Sustainability Handprints}

Changes, actions, innovations and impacts to promote (1) capacities related to equity for societal aspects of sustainable development and societal sustainability (e.g., empowerment of actors in weaker positions), (2) equity, inequity, fairness and justice (e.g., distribution of resources within and between generations) and (3) equality in access to resources (e.g., policies to promote societal sustainability goals)

Changes, actions, innovations and impacts to promote (1) public deliberation, (2) participatory decision making and (2) bottom-up governance to address problems related to and to promote sustainable social/society-environment relationships and interfaces

Changes, actions, innovations and impacts to promote (1) knowledge structuring based on inter- and transdisciplinary approaches and expertise, (2) the creation of an interdisciplinary intellectual base, (3) action-structuring based on decomposition of actions, integration into new actions and promotion of collective actions and (4) knowledge and actions to change situations to promote and manage societal sustainability

Changes, actions, innovations and impacts to promote responses and solutions to sustainability problems faced by public-policy makers based on (1) multidisciplinary approaches to problem-structuring and (2) multiple problem identification perceptions of societal sustainability and sustainable social/society-environment relationships and interfaces by various participants

Changes, actions, innovations and impacts to promote sustainable interactions of society and nature as a complex, adaptive and globally interconnected system considering (1) innovation, heterogeneity and nonlinear relationships, (2) unpredictable nature of the dynamics of the system and (3) possibility for partial guidance through appropriate interventions

Changes, actions, innovations and impacts to promote (1) societal well-being, (2) human health, (3) ecosystem services, (4) social systems that consider sustainable interactions between humans and the biological systems as indicators of sustainability accomplishments and (5) the maintenance and restoration of biodiversity in ecosystems

Changes, actions, innovations and impacts to promote (1) integration of societal, environmental and industrial systems and (2) decision support systems that assess societal and environmental impacts and take into account inputs from societies including all ethical considerations

(1) Societal sustainability problems include complex and dynamic interplay of interests, incentives and causalities among multiple stakeholders in multiple cultural, historical and geographical contexts and (2) addressing these problems needs to be based on understanding of and dealing with a whole system in an integrative way taking into account multi-, interand transdisciplinary work [112]
Changes, actions, innovations and impacts to promote solutions to societal sustainability problems considering multiple stakeholders in various cultural, historical and geographical contexts and based on integrative, transdisciplinary and whole system level approaches

In addition, these findings suggest that the assessment of social sustainability handprints needs to integrate (1) quality of life indicators, (2) societal sustainability indicators to establish or change direction, assess progress and to get warnings of unsustainability, (3) 
whole-system-level and integrated approaches, (4) social diversity and multiple stakeholders, (5) societal accountability of organizational management including assessment of all outcomes and use of resources based on criteria that reflect the norms and values of the society and (6) sustainable social/society-environment relationships and interfaces into assessment, development of indicators and collection of information.

\subsection{Sustainability Assessment}

Sustainability assessment encompasses multiple elements and approaches that have implications for the assessment of social sustainability handprints. Sustainability assessment is based on the sustainability concept within the decision-making context [119] and on context dependent, universal and open-ended processes with intertwined ends and means that contribute to the pursuit of sustainability and to the definition of local sustainability particulars in specific circumstances and contexts [72]. Sustainability assessment is a globally applied tool for directing decision making towards sustainability including a broad and continuously evolving range of processes [119]. Previous studies have recognized that sustainability assessment approaches (1) use sustainability indicators [47], (2) integrate sustainability concepts into decision making through multiple processes [120], (3) support strategic decision making [18] and (4) focus on decision-making processes including assessment of whether, e.g., initiatives, plans or policies will lead society to more sustainable direction [88]. In addition, previous studies have recognized the following important aspects of sustainability assessment approaches:

- The measurement and monitoring of progress toward sustainability [121] and reflexiveness about issue definition and criteria for sustainable solutions [122].

- The integration of ecological, social and economic considerations [61].

- Operationalization of sustainability in the context of sustainability assessment including comprehensive considerations and interrelations and interdependency over the short- and long-term and application by governments, civil society organizations and companies at both strategic and project levels [52].

- Multiple approaches to align decision making with sustainability principles (including problem analysis, mapping of options and assessment of alternatives) and operationalization of sustainability for decision making based on structuring of unstructured sustainability issues [122].

- Inclusion of various specific aspects such as (1) intra- and intergenerational equity, (2) socio-ecological system integrity, (3) livelihood sufficiency and opportunity, (4) resource maintenance and efficiency, (5) socio-ecological civility and democratic governance, (6) precaution and adaptation and (7) immediate and long-term integration [72].

These findings suggest that the assessment of social sustainability handprints needs to integrate (1) operationalization of sustainability including direction of decision making towards sustainability and aligning decision making with sustainability principles (problem analysis, mapping of options, assessment of alternatives and structuring of unstructured sustainability issues), (2) context dependent, continuously evolving, universal and openended processes with intertwined ends and means, (3) local sustainability particulars in specific circumstances and contexts, (4) comprehensive considerations and interrelations and interdependency over the short- and long-term, (5) social sustainability indicators, (6) assessment of initiatives, plans and policies (are they leading towards a more sustainable society), (7) ecological, social and economic considerations, (8) progress toward sustainability and criteria for sustainable solutions, (9) application by governments, civil society organizations and companies at both strategic and project levels and (10) specific aspects such as intra- and intergenerational equity, socio-ecological system integrity, democratic governance, precaution and immediate/long-term integration. Further implications of sustainability assessment approaches for the assessment of social sustainability handprints are presented in Table 8. 
Table 8. Implications of sustainability assessment approaches for the assessment of social sustainability handprints.

\begin{tabular}{l} 
Sustainability Assessment Elements and Approaches \\
\hline (1) Addressing sustainability priorities and progress towards \\
sustainability, (2) direction of decision making towards \\
sustainability, (3) application to any type of decision making \\
including different levels, contexts and approaches and (4) \\
operationalization of the sustainability concept in the context of \\
decision making and assessments [123]
\end{tabular}

Integration of assessment and management tools into decision making and planning processing [124]

(1) The definition of local sustainability particulars (specific location, context and circumstances), (2) the pursuit of sustainability (requirements of progress toward sustainability and general sustainability criteria for decision making and evaluation) and (3) promotion of positive steps towards enhanced community and ecological sustainability and more viable, secure and pleasant future [72]

(1) Systemic (e.g., scope, scales and environmental, social and economic interrelations/impacts), (2) normative (e.g., incorporation of sustainability principles and dimensions and context-specific perceptions), (3) strategic (e.g., purpose, decision and action support, broader context and consideration of alternatives) and (4) transdisciplinary (e.g., knowledge, actors and stakeholder engagement) approaches [27]

Sustainability or social sustainability perspective to assessment typically applies a multi-dimensional index that integrates processes and factors of some focus area [100]

Analysis of organizations based on (1) their relative commitment to the social pillar of sustainable development with respect to the other pillars of sustainable development and to their commitment to develop interpillar relationships and (2) indicators (based on, e.g., equity, awareness of sustainability, participation and social cohesion dimensions of the social-environmental framework) [103]

(1) Effective tool to promote and support decision making for sustainable development and to provide guidance towards a sustainable society, (2) operationalization of sustainable development for a specific system in a particular socio-environmental context, (3) addressing sustainability decision-making challenges including interpretation (principles and socio-environmental context), information-structuring (complex and multi-dimensional sustainability into indicators) and influence (of sustainability information on decision making and implementation of sustainable development), (4) generation of sustainability information (well-structured approach to inform decision making), (5) identification of knowledge and data gaps and (6) advancement of continuous social learning (decision makers and stakeholders), debate and participation [16]
Social Sustainability Handprint Assessment Approaches

Integration of (1) sustainability priorities, (2) progress towards sustainability, (3) direction of decision making towards sustainability, (4) application to decision making at all levels and in all contexts) and (5) operationalization of the sustainability concept in the context of decision making into assessment, development of indicators and collection of information

Integration of (1) management and assessment tools and (2) decision making and planning processes into assessment, development of indicators and collection of information

Integration of (1) local sustainability particulars in specific locations, contexts and circumstances, (2) requirements of progress towards sustainability, (3) sustainability criteria for decision making and (4) positive steps towards community sustainability, sustainable social/society-environment relationships and interfaces and sustainable future into assessment, development of indicators and collection of information

Integration of (1) systemic (e.g., scope, scales and social and environmental impacts), (2) normative (e.g., sustainability principles and dimensions and context-specific perceptions), (3) strategic (e.g., purpose, decision and action support, broader context and consideration of alternatives) and (4) transdisciplinary (e.g., knowledge, actors and stakeholder engagement) elements and approaches into assessment, development of indicators and collection of information

Integration of multi-dimensional indices that integrate processes and factors of focus areas into assessment, development of indicators and collection of information

Assessment of organizations based on the integration of (1) commitment to social aspects of sustainable development including social/society-environment relationships and interfaces and (2) sustainability indicators (e.g., equity, awareness of sustainability, participation, social cohesion and social-environmental framework) into assessment, development of indicators and collection of information

Integration of (1) decision making for sustainable development, (2) guidance towards a sustainable society, (3) operationalization of sustainable development for specific systems in particular socio-environmental contexts, (4) sustainability decision-making challenges, (5) interpretation of principles and socio-environmental context, (6) infor-mation-structuring (e.g., multi-dimensional sustainability into indicators), (7) influence of sustainability information on decision making and implementation of sustainable development, (8) identification of knowledge and data gaps and generation of sustainability information, (9) well-structured approaches to inform decision making and (10) advancement of continuous social learning (e.g., decision makers and stakeholders) debate and participation into assessment, development of indicators and collection of information 
Table 8. Cont.

\begin{tabular}{|c|c|}
\hline Sustainability Assessment Elements and Approaches & Social Sustainability Handprint Assessment Approaches \\
\hline $\begin{array}{l}\text { Evaluation of sustainability transition experiments covering (1) } \\
\text { societal effects such as institutional change (organizations and } \\
\text { decision making, governance and policies), ( } 2 \text { ) process (e.g., } \\
\text { conceptualization of sustainability, inclusiveness, transparency, } \\
\text { fairness, approaches, governance and reflexive and adaptive } \\
\text { capacity) and (3) sustainability transition impacts (e.g., } \\
\text { long-term sustainability impacts that reflect societal transition) } \\
\text { [125] }\end{array}$ & $\begin{array}{l}\text { Assessment of sustainability transitions based on the integration } \\
\text { of (1) social effects, (2) institutional changes (organizations, } \\
\text { decision making, governance and policies), (3) processes (e.g., } \\
\text { governance, inclusiveness, transparency, fairness and reflexive } \\
\text { and adaptive capacity) and (4) impacts (e.g., long-term } \\
\text { sustainability impacts related to societal transitions) into } \\
\text { assessment, development of indicators and collection of } \\
\text { information }\end{array}$ \\
\hline $\begin{array}{l}\text { (1) Integrated approach (e.g., to explore solutions to enduring } \\
\text { problems), (2) sustainability-oriented, strategic, constructive } \\
\text { and potentially transformative, (3) a cyclical and participatory } \\
\text { process encompassing envisioning, scoping, experimenting and } \\
\text { learning to establish and apply an interpretation of } \\
\text { sustainability for a specific context, (4) exploration of } \\
\text { problem-solving and opportunity-creation potential of } \\
\text { alternative framing contexts (e.g., institutions, policy regimes } \\
\text { and technologies) and (5) establishment and application of } \\
\text { sustainability interpretations for a specific context through an } \\
\text { integrated approach to explore solutions to sustainability } \\
\text { problems [126] }\end{array}$ & $\begin{array}{l}\text { Integration of (1) exploration of solutions to enduring problems, } \\
\text { (2) sustainability-oriented, strategic, constructive and } \\
\text { transformative approaches, (3) cyclical and participatory } \\
\text { processes including envisioning, scoping, experimenting and } \\
\text { learning to establish and apply an interpretation of } \\
\text { sustainability for specific contexts, (4) exploration of } \\
\text { problem-solving and opportunity-creation potential of } \\
\text { alternative framing contexts (e.g., institutions, technologies and } \\
\text { policy regimes) and (5) establishment and application of } \\
\text { sustainability interpretations for specific contexts based on } \\
\text { integrated approaches to explore solutions to sustainability } \\
\text { problems into assessment, development of indicators and } \\
\text { collection of information }\end{array}$ \\
\hline $\begin{array}{l}\text { Assessment of urban sustainability based on (1) an integrative } \\
\text { approach using common sustainability principles and } \\
\text { goal-based framework and (2) sustainability and sustainable } \\
\text { development indicator or index frameworks including social, } \\
\text { environmental and economic dimensions (as well as integrative } \\
\text { dimensions such as social-environmental or institutional such as } \\
\text { good governance) [127] }\end{array}$ & $\begin{array}{l}\text { Assessment of urban sustainability based on the integration of } \\
\text { (1) common sustainability principles and goal-based framework, } \\
\text { (2) sustainability and sustainable development indicator and/or } \\
\text { index frameworks, (3) social and environmental dimensions, (4) } \\
\text { integrative dimensions such as social/society-environment } \\
\text { relationships and interfaces and (5) institutional dimensions } \\
\text { such as good governance including institutional dimensions } \\
\text { into assessment, development of indicators and collection of } \\
\text { information }\end{array}$ \\
\hline $\begin{array}{l}\text { Support of decision making and policy within a broad social, } \\
\text { environmental and economic context based on complex } \\
\text { appraisal methods that go beyond technical and scientific } \\
\text { evaluation [128] }\end{array}$ & $\begin{array}{l}\text { Integration of (1) support of informed decision making and } \\
\text { policy, (2) broad social and environmental context and (3) } \\
\text { advanced appraisal methods that go beyond technical and } \\
\text { scientific evaluation into assessment, development of indicators } \\
\text { and collection of information }\end{array}$ \\
\hline
\end{tabular}

\subsection{Sustainability Assessment Development Focus Areas}

There are many sustainability assessment development focuses that have implications for the assessment of social sustainability handprints. The effective use of sustainability assessment and management approaches requires that they are integrated into existing decision making and planning processes or adaptation of other decision-making processes [124]. The design of sustainability assessments need to be based on an integrative process to build a framework for decision making including the integration of social, ecological and economic considerations [61]. In addition, sustainability-based decision making needs to be based on continuous learning, testing, adjustment and development of better understanding about durable and desirable ways of living on the planet [52] considering the complex nature of, e.g., the relationships between human systems and ecosystems [50]. In addition, previous studies have recognized the importance of the following sustainability assessment development focus areas:

- In-depth knowledge about all parameters that have an effect on sustainability and assessment of the progress of a nation towards sustainability based on all parameters and their individual and combined impacts on all pillars of sustainability [21].

- (1) The integration, promotion and accomplishment of learning, (2) inclusion of the views of all affected and interested parties in the framing of the assessment and (3) 
the application of mechanisms for managing trade-offs based on open, accountable and participative approaches [123].

- Design to initiate innovative and creative thought processes to solve sustainable development problems and a communicative process to improve communication about sustainability issues [88].

- Information about (1) ecosystem services, (2) trends in human use of ecosystem services, (3) changes in institutions and governance arrangements and (4) trends in components of human well-being (particular focus on aspects outside traditional measurement) to manage human-environment systems [67].

These findings suggest that the assessment of social sustainability handprints needs to integrate (1) existing and development of new decision making and planning processes and frameworks including integrative aspects, (2) social/society-environment relationships and interfaces including the complex nature of the relationships between human systems and ecosystems and the integration of social and ecological considerations, (3) continuous learning, testing, adjustment and development of better understanding about durable and desirable ways of living on the planet, (4) all aspects, elements and parameters (including their interrelations and individual and combined impacts) that have an effect on and can assess progress towards sustainability, (5) the promotion and accomplishment of learning, (6) inclusion of the views of all affected and interested parties, (7) management of trade-offs based on open, accountable and participative approaches, (8) design and innovative and creative thought processes to solve sustainable development problems, (9) a communicative process to improve communication about sustainability issues and (10) information about changes and trends in human well-being and human use of ecosystem services (particular focus on aspects outside traditional measurement) including social/society-environment relationships and interfaces into assessment, development of indicators and collection of information. Further implications of sustainability assessment development focus areas for the assessment of social sustainability handprints are presented in Table 9.

Table 9. Implications of sustainability assessment approaches for the assessment of social sustainability handprints.

\begin{tabular}{|c|c|}
\hline Sustainability Assessment Development Focus Areas & Social Sustainability Handprint Assessment Approaches \\
\hline $\begin{array}{l}\text { (1) Integrated assessment including incorporation of } \\
\text { sustainability goals and proactive promotion of positive impacts } \\
\text { (broad solution-oriented approach and scope that goes beyond } \\
\text { comparative and analysis-oriented approach and avoidance of } \\
\text { negative impacts), (2) holism and transdisciplinarity, (3) } \\
\text { co-production of knowledge (e.g., science-policy interface), (4) } \\
\text { multiple geographical and temporal scales (from local to global), } \\
\text { (5) stakeholder involvement and commitment, (6) } \\
\text { determination of who is entitled to carry out the assessment and } \\
\text { (7) identification of targets based on bottom-up approach and } \\
\text { broadly supported and widely shared development process } \\
\text { [128] }\end{array}$ & $\begin{array}{l}\text { Integration of (1) sustainability goals, (2) identification of targets } \\
\text { based on bottom-up approaches and broadly supported and } \\
\text { widely shared development processes, (3) proactive promotion } \\
\text { of positive impacts (broad solution-oriented approach and } \\
\text { scope), (4) holistic and transdisciplinary approaches, (5) } \\
\text { co-production of knowledge, (6) multiple geographical and } \\
\text { temporal scales (from local to global), (7) stakeholder } \\
\text { involvement and commitment and (8) determination of who is } \\
\text { entitled to carry out the assessment into assessment, } \\
\text { development of indicators and collection of information }\end{array}$ \\
\hline $\begin{array}{l}\text { (1) Use of collaborative scientific innovation and development } \\
\text { as basis for change and (2) addressing new local and global } \\
\text { paradigms [129] }\end{array}$ & $\begin{array}{l}\text { Integration of (1) collaborative scientific innovation and } \\
\text { development as a basis for changes and (2) new local and global } \\
\text { paradigms into assessment, development of indicators and } \\
\text { collection of information }\end{array}$ \\
\hline $\begin{array}{l}\text { Active engagement of supply chain and integrated approach to } \\
\text { sustainable supply chain management and product } \\
\text { development are important in the context of social sustainability } \\
\text { assessment [130] }\end{array}$ & $\begin{array}{l}\text { Integration of (1) active supply chain engagement, (2) integrated } \\
\text { approaches to sustainable supply chain management and (3) } \\
\text { product development into assessment, development of } \\
\text { indicators and collection of information }\end{array}$ \\
\hline $\begin{array}{l}\text { (1) Consideration of environmental, social and economic issues, } \\
\text { (2) the context of the assessment (e.g., planning context), (3) } \\
\text { prediction of future conditions, (4) comparison of the likely } \\
\text { results of various actions and (5) presentation and } \\
\text { communication of findings to decision makers and stakeholders } \\
\text { [131] }\end{array}$ & $\begin{array}{l}\text { Integration of (1) social/society-environment relationships and } \\
\text { interfaces, (2) the context of the assessment, (3) prediction of } \\
\text { future conditions, (4) comparison of the likely results of various } \\
\text { actions and (5) presentation and communication of results to } \\
\text { decision makers and stakeholders into assessment, } \\
\text { development of indicators and collection of information }\end{array}$ \\
\hline
\end{tabular}


Table 9. Cont.

Sustainability Assessment Development Focus Areas

(1) The choice of tools and metrics based on highlighted context and characteristics, (2) consideration of the underlying assumptions and features of the applied tools to ensure transparency of the result, (3) the use of a variety of tools based on a choice guided by the assessment context (a good idea because no individual tool can encompass all sustainability perspectives), (4) addressing the lack of capability to assess progress towards sustainability in a holistic way (e.g., focus on multiple social, environmental and economic issues jointly with inter- and intragenerational equity aspects), (5) integration of social, environmental and economic (increasingly also institutional) issues and consideration of associated interdependencies, (6) inclusion of inter- and intragenerational equity considerations, (7) consideration of the future consequences of present actions, (8) acting with a precautionary bias and acknowledgement of the uncertainties related to the results of present actions and (9) engagement of the public [132]

The development of social and cultural sustainability assessments including focus on the development of indicators, verifier variables and target levels [133]

(1) The ability to continue and develop a desirable way of living taking into account future generations, values and beliefs of people about the way societies sustain quality of life and life in other places of the planet and (2) an integrated framework that aims at developing and continuing quality of human life (also in other places and in the future) within ecological and social limits [18]

Observation systems that (1) encompass both social and environmental phenomena, (2) include multiple types of information (qualitative, narrative, quantitative data and historical records), (3) support decision making and scientific understanding and (4) address significant changes and assess resilience and vulnerability [67]

(1) Integration into government decision making including recognition of the need to assess the interdependencies between human activities and the environment early in the decision-making process, the need for informed decision-making and participation and openness of the decision makers to a process of change and (2) qualitative approaches that may increase the quality of discussions on the introduction of the sustainable development principles into functioning of societies [88]
Social Sustainability Handprint Assessment Approaches

Integration of (1) the selection of tools and metrics based on context and its characteristics, (2) the consideration of the underlying assumptions and features of the applied tools to ensure transparency of the result, (3) the use of a variety of tools based on the assessment context to encompass all sustainability perspectives, (4) capability to assess progress towards sustainability in a holistic way (e.g., social/society-environment relationships and interfaces), (5) social, institutional and environmental issues including associated interdependencies, (6) inter- and intragenerational equity, (7) future consequences of present actions, (8) acting with a precautionary bias and acknowledgement of the uncertainties related to the results of present actions and (9) engagement of the public into assessment, development of indicators and collection of information

Assessment of social and cultural sustainability including development of indicators, verifier variables and target levels

Integration of (1) abilities to continue and develop desirable ways of living considering future generations, values and beliefs of people, (2) the way societies sustain quality of life and life in other places of the planet and (3) development and continuing of the quality of human lives (including future and other places) within social and ecological limits into assessment, development of indicators and collection of information

Integration of (1) observation systems, (2) social and environmental phenomena, (3) multiple types of information (qualitative, narrative, quantitative data and historical records), (4) decision making, (5) scientific understanding, (6) significant changes and (7) resilience and vulnerability into assessment, development of indicators and collection of information

Integration of (1) informed decision making (e.g., government), (2) early assessment of the interdependencies between human activities and the environment in decision making processes, (3) participation and openness of the decision makers to change processes and (4) qualitative approaches to introduce social and societal aspects of sustainable development principles into functioning of societies into assessment, development of indicators and collection of information

\subsection{Sustainability Indicators}

Sustainability indicators are essential parts of sustainability and sustainable development including sustainability management and assessment. There are multiple sustainability indicator definitions and elements that have implications for the assessment of social sustainability handprints. Previous studies have recognized that (1) sustainability assessment is based on sustainability indicators [47], (2) sustainable development indicators should be selected, revisited and refined based on the appropriate communities of interest [134], (3) reaching sustainable development requires the use of indicators taking into account all views, issues, actions and diversities (a sustainable development indicator system is an essential platform) [48], (4) the transition towards sustainability takes place through the application of a new set of values-based indicators to measure the implementation of ethical principles [71] and (5) multiple sustainability indices address 
community, environment and economy parts of sustainable development and their interactions [135]. In addition, previous studies have recognized the following important aspects of sustainability indicator approaches:

- Internationally negotiated consensus on priority human needs goals, targets and indicators as a basis and focus on the assessment of the achievement of goals and targets and of progress towards or away from a sustainability transition [64].

- (1) Support of decision making for and to promote sustainable development, (2) operationalization of sustainable development for a specific system in a particular socioenvironmental context, (3) generation and communication of complex sustainability information (well-structured approach to inform decision making), (4) identification of knowledge and data gaps and (4) advancement of continuous social learning (decision makers and stakeholders) [16].

- (1) Assessment and communication of the progress toward sustainable development, (2) support of all levels of decision making and policy processes (e.g., strategies, policies, plans, operations, activities, programs and projects) and (3) improvement of the management of both human and natural systems [128].

- Identification (including making them visible) and management of essential dimensions of society and the environment [71].

- (1) Mapping progress toward meeting human needs (including specific indicators of human welfare) and preserving life support systems, (2) evaluation of the effectiveness of applied actions to achieve the goals, (3) informing the society about the nature and progress of the sustainability transition and (4) contribution to information feedback system of society to adjust directions, assess progress and gain unsustainability warmings [58].

In addition, sustainability indicators are about the provision of information to support decision making about, for example, the future directions of society [53] and an important policy making and public communication tool including information on national and corporate social, environmental and economic performance [134]. They are also tools to identify and enable the management of society and environment related dimensions and progress towards sustainability (change in dynamic systems) including addressing challenges such as climate change and resource limits [71] and a part of the institutional framework for sustainability to assess and monitor progress and value [75]. Sustainability indicators can be based on multiple qualitative, quantitative or combined approaches and used to, e.g., report on and communicate about sustainability and to measure the characteristics or processes of the human-environmental system to ensure its functionality and continuity far into the future [53]. Previous studies have also recognized that sustainability indicator approaches encompass the following important aspects:

- (1) Promotion and support of decision making for sustainable development, (2) provision of guidance towards a sustainable society, (3) addressing sustainability decisionmaking challenges including interpretation (principles and socio-environmental context), information-structuring (complex and multi-dimensional sustainability into, e.g., indicators) and influence (of sustainability information on decision making and implementation of sustainable development), (4) interpretation of sustainability, (5) impact measurement and (6) promotion of social learning, debate and participation [16].

- (1) Evaluation of what really matters to track progress toward a sustainable society, (2) dealing with volatile contradictory societal values, new information traps and post-truth reality and (3) individuals as leading actors including their role in the collection, analysis, evaluation and communication of sustainability information and data covering households, daily activities and urban and rural ecosystems [128].

- (1) Sustainability transition through the operationalization of goals into specific indicators that can be continuously monitored, evaluated and reported, (2) responsibility by societies to take measure of the desired development direction and (3) sustainability transition reporting based on multiple indicators to both map progress toward the 
associated goals (meeting human needs and preserving life support systems) and to evaluate the effectiveness of applied actions to achieve the goals [58].

These findings suggest that the assessment of social sustainability handprints needs to integrate (1) social sustainability indicators and indicators for social and societal aspects of sustainable development based on the appropriate communities of interest, (2) the application of indicators taking into account all views, issues, actions and diversities, (3) the application of a new set of values-based indicators to measure the implementation of ethical principles, (4) multiple sustainability indices that address community and environment parts of sustainable development including social/society-environment relationships and interfaces, (5) internationally negotiated consensus on priority human needs goals, targets and indicators, (6) the achievement of goals and targets and of progress towards or away from sustainable development, a sustainability transition, meeting human needs and welfare and preservation of life support systems, (7) informed decision making, the identification of knowledge and data gaps and continuous social learning, (8) management of essential dimensions of society and the environment, (9) societal information feedback system to adjust directions, assess progress and produce unsustainability warmings and (10) information about the future directions of society into assessment, development of indicators and collection of information. In addition, the following aspects need to be integrated into social sustainability handprint assessment approaches including development of indicators and collection of information:

- Corporate social and environmental performance and management of society and environment related dimensions and progress towards sustainability (change in dynamic systems) including climate change and resource limit challenges.

- Institutional framework for sustainability to assess and monitor progress and value and sustainability indicators based on multiple qualitative, quantitative or combined approaches (e.g., to assess the characteristics or processes of the human-environmental system to ensure its functionality and continuity far into the future).

- Assessment of what really matters to track progress toward a sustainable society and societal values and individuals as leading actors in the collection, analysis, evaluation and communication of sustainability information and data (e.g., households, daily activities and urban/rural ecosystems).

The assessment of social sustainability handprints also needs to integrate (1) decision making for sustainable development, provision of guidance towards a sustainable society and social learning, debate and participation, (2) the operationalization of goals into specific indicators that can be continuously monitored, evaluated and reported, (3) assessment of the desired development direction by societies and (4) sustainability transition reporting based on multiple indicators (to assess progress toward meeting human needs, preservation of life support systems and the effectiveness of applied actions to achieve these goals) into assessment, development of indicators and collection of information. Further implications of sustainability indicator approaches for the assessment of social sustainability handprints are presented in Table 10.

Table 10. Implications of sustainability indicator approaches for the assessment of social sustainability handprints.

\begin{tabular}{|c|c|}
\hline Sustainability Indicator Approaches & Social Sustainability Handprint Assessment Approaches \\
\hline $\begin{array}{l}\text { (1) Indication of progress toward or away from sustainable } \\
\text { development goals to advise decision makers, managers and the } \\
\text { public, (2) multiple sustainability indices that address } \\
\text { community, environment and economy parts of sustainable } \\
\text { development and their interactions and (3) measurement and } \\
\text { characterization of sustainability including choices about how } \\
\text { to define and quantify what is being developed and about what } \\
\text { is being sustained and for how long [136] }\end{array}$ & $\begin{array}{l}\text { Integration of (1) progress toward or away from sustainable } \\
\text { development goals to advise decision makers, managers and the } \\
\text { public, (2) multiple sustainability indices that ad-dress } \\
\text { community and environment parts of sustainable development } \\
\text { and their interactions, (3) characterization of sustainability, (4) } \\
\text { choices about how to define and quantify what is being } \\
\text { developed and (5) choices about what is being sustained and for } \\
\text { how long into assessment, development of indicators and } \\
\text { collection of information }\end{array}$ \\
\hline
\end{tabular}


Table 10. Cont.

\begin{tabular}{l} 
Sustainability Indicator Approaches \\
\hline (1) Simplifying tools (similarly to indices) that are designed to \\
address complexity and provide information to both specialists \\
and non-specialists and (2) multiple indicators (and indices) to \\
influence the people in power and the public to do wiser things \\
[137]
\end{tabular}

(1) Development and use by national, regional and local governments, local communities, business organizations and non-governmental organizations, (2) measurement of progress towards sustainable development goals and (3) contribution to a more sustainable society for future generations [138]

(1) Use in decision making taking into account placing in a specific cultural context and the relevant people and processes, (2) qualitative and quantitative indicators, (3) addressing critical sustainability issues in a specific context in a comprehensive way, (4) what is measured depending on the goal of specific intervention, (5) monitoring to support development and use and (6) addressing future scenarios [139]

Roles in sustainability science: (1) support of management and policy decision making, (2) improvement of knowledge about socio-ecological systems and (3) addressing relationships between intergenerational well-being and specific capital assets [140]

(1) Monitoring of progress towards or away from sustainability, (2) addressing changes of interconnected social and ecological features of a system taking into account (social-ecological) systems thinking, (3) design to measure based on systems approach including interdependent parts of the system and (4) potential to change the perceptions of goals and values about how that system should be managed [141]

(1) Capturing the measure of sustainability (progress towards sustained social, environmental and economic outcomes), (2) measurement of social, environmental and economic processes to support decision making to enhance social and environmental outcomes, (3) complex and varied as the definition of sustainability and (4) a systems approach as a basis in which all aspects are interlinked [142]

(1) Promotion of compliance with the principles for sustainability, (2) assessment of the relevance, quality and quantity of activities to ensure alignment with the principles of sustainable development and (3) monitoring the ecosphere-society system and its impacts [143,144]

(1) Framework that is comprehensive, understandable to the society, information-driven, transparent, covers the whole process (monitor, assess, learn, decide and act) and supports decision making by people and (2) multiple sources (e.g., social, environmental and economic processes) as a basis and provision of indications of change [145]
Social Sustainability Handprint Assessment Approaches

Integration of (1) simplifying tools that are designed to address complexity and provide information to both specialists and non-specialists and (2) multiple indicators and indices to influence the people in power and the public to do wiser things into assessment, development of indicators and collection of information

Integration of (1) development and use by national, regional and local governments, local communities, business organizations and non-governmental organizations, (2) progress towards sustainable development goals and (3) contribution to a more sustainable society for future generations into assessment, development of indicators and collection of information

Integration of (1) use in decision making, (2) placing in specific cultural contexts, (3) the relevant people and pro-cesses, (4) qualitative and quantitative indicators, (3) critical sustainability issues in specific contexts, (4) what is measured depending on the goals of specific interventions, (5) monitoring to support continuous improvements and (6) future scenarios into assessment, development of indicators and collection of information

Integration of (1) sustainability science, (2) management and policy decision making, (2) knowledge about socio-ecological systems and (3) intergenerational well-being into assessment, development of indicators and collection of information

Integration of (1) progress towards or away from sustainability, (2) changes of interconnected social and ecological features of systems, (3) social-ecological systems thinking, (4) a systems approach including interdependent parts of systems and (5) potential to change the perceptions of goals and values about how that system should be managed into assessment, development of indicators and collection of information

Integration of (1) progress towards sustained social and environmental outcomes), (2) social and environmental processes, (3) decision making to enhance social and environmental outcomes, (4) broad and diverse social sustainability indicators and (5) a systems approach in which all aspects are interlinked into assessment, development of indicators and collection of information

Integration of (1) compliance with the principles of sustainability, (2) the relevance, quality and quantity of activities to ensure alignment with the principles of sustainable development and (3) the ecosphere-society system and its impacts into assessment, development of indicators and collection of information

Integration of (1) comprehensive, information-driven and transparent social sustainability indicator framework that is understandable to the society, covers the whole process (monitor, assess, learn, decide and act) and supports decision making by people, (2) multiple sources (e.g., social and environmental processes) and (3) provision of indications of change into assessment, development of indicators and collection of information 
Table 10. Cont.

\begin{tabular}{|c|c|}
\hline ndicator Approaches & Social Sustainability Handprint Assessment Approaches \\
\hline $\begin{array}{l}\text { Social sustainability indicators (1) address the integration of } \\
\text { multidimensional and intergenerational issues that are essential } \\
\text { to the sustainability concept, (2) are selected in a way that is } \\
\text { informed by sustainability principles and objectives based on } \\
\text { participation process involving stakeholders and local agents, } \\
\text { (3) are process indicators that assess the processes that define, } \\
\text { agree themes for and implement solutions for sustainability } \\
\text { principles and objectives and (4) assess progress towards } \\
\text { specific objectives in an interactive way and allow monitoring of } \\
\text { actual implementation [100] }\end{array}$ & $\begin{array}{l}\text { intergenerational issues, (2) selection b } \\
\text { principles and objectives through a par } \\
\text { involving stakeholders and local agent } \\
\text { to assess the processes that define, agre } \\
\text { implement solutions for sustainability } \\
\text { and (4) progress towards specific objec } \\
\text { way including assessment of actual im } \\
\text { assessment, development of indicators } \\
\text { information }\end{array}$ \\
\hline $\begin{array}{l}\text { inability based on } \\
\text { and satisfaction of } \\
\text { ning, income, } \\
\text { itions, } \\
\text { vith work, } \\
\text { (2) equal } \\
\text { nigrants) and (3) } \\
\text { vement in activities }\end{array}$ & $\begin{array}{l}\text { tor } \\
\text { (health, } \\
\text { on, } \\
\text { ctive } \\
\text { nd } \\
\text { r and } \\
\text {, }\end{array}$ \\
\hline $\begin{array}{l}\text { ss (1) living } \\
\text { safety, (2) equity (e.g., } \\
\text { an development (e.g., } \\
\text { c civil society (e.g., }\end{array}$ & $\begin{array}{l}\text { es: (1) } \\
\text { y, (2) } \\
\text { in } \\
\text { locratic } \\
\text { ssessment, } \\
\text { on }\end{array}$ \\
\hline $\begin{array}{l}\text { include: (1) } \\
\text { he } \\
\text { he } \\
\text { tability and }\end{array}$ & $\begin{array}{l}\text { community, (3) safety and security, (4) community stabi } \\
\text { (5) sense and pride of place into assessment, developm } \\
\text { ndicators and collection of information }\end{array}$ \\
\hline
\end{tabular}

\subsection{Sustainability Indicator Development Focus Areas}

There are many development focus areas related to sustainability indicators and continuous development, innovation and responses to emerging issues are highly important. Previous studies have recognized that (1) the development of sustainable development and sustainability indicators needs to address action towards change and improvement of the quality of human lives [17], (2) there are both objective and subjective approaches to sustainability indicators and of shortcomings related to any statistical means to address complex truths [137], (3) the development of new sustainability indicators is focusing on the measurement of emerging themes and that too narrow assessment approaches are harmful for a meaningful progress in social sustainability assessment [100], (4) the development of sustainability indicators and indices should take into account their use and the needs of users [135] and (5) the users of sustainable development indicator metrics must have understanding about the foundations of specific metric including its limitations due to various definitions and conceptualizations of sustainability [50]. In addition, previous studies have also recognized the following important sustainability indicator development focus areas:

- Capturing of social, environmental and economic priorities of projects and conflicts between human well-being, environmental conservation and economic development [139]. 
- Human-environment vulnerability including indicators that monitor the combination of social and natural factors that lead to irreversible damage [58].

- Indicators of (1) progress towards sustainability and (2) change in dynamic systems to address challenges (e.g., climate change and resource limits) [71].

- Specific issues such as (1) equity, (2) awareness of sustainability, (3) participation and (4) social cohesion dimensions of the social-environmental framework (for the analysis of organizations) [103].

- The development of a concise set of fully integrated indicators covering essential sustainable development variables that define the main minimum set of social, environmental and economic monitoring measurements to link across actors, sectors and countries to promote monitoring, accountability and data for the implementation of sustainable development goals [51].

These findings suggest that the assessment of social sustainability handprints needs to integrate (1) the development of sustainable development and sustainability indicators that address action towards change and improvement of the quality of human lives, (2) objective and subjective approaches to sustainability indicators, (3) the development of new sustainability indicators and indices to assess all emerging themes considering their intended uses and the needs of various users, (4) the promotion of the understanding of various users about sustainable development indicators and metrics including limitations due to various definitions and conceptualizations of sustainability, (5) social/societyenvironment relationships and interfaces including social and environmental priorities of projects and conflicts between human well-being and environmental conservation, (6) human-environment vulnerability including indicators that assess the combination of social and natural factors that lead to irreversible damage, (7) indicators of progress towards sustainability and of change in dynamic systems to address climate change and resource limit challenges, (8) the assessment of organizations based on equity, awareness of sustainability, participation and social cohesion dimensions of the social-environmental framework and (9) the development of a set of fully integrated indicators to implement sustainable development goals based on reliable sources of information and covering essential sustainable development elements (that define the main social aspects and aspects related to social/society-environment relationships and interfaces including linkages across actors, sectors and countries) into assessment, development of indicators and collection of information. Further implications of sustainability indicator development focus areas for the assessment of social sustainability handprints are presented in Table 11.

Table 11. Implications of sustainability indicator development focus areas for the assessment of social sustainability handprints.

\begin{tabular}{ll}
\hline \multicolumn{1}{c}{ Sustainability Indicator Development Focus Areas } & \multicolumn{1}{c}{ Social Sustainability Handprint Assessment Approaches } \\
\hline $\begin{array}{l}\text { Development of new indicators to effectively assess and report } \\
\text { sustainable development through robust, collaborative and } \\
\text { open approaches, (2) focus on societal role and impacts, } \\
\text { end-users, practitioners, communities and individuals, (3) } \\
\text { adaptation of thinking and doing by researchers and (4) } \\
\begin{array}{l}\text { assessments that use collaborative scientific innovation and } \\
\text { development as basis for change and address new local and } \\
\text { global paradigms [129] }\end{array}\end{array}$ & $\begin{array}{l}\text { sustainable development through robust, collaborative and } \\
\text { open approaches, (2) societal role and impacts, (3) end-users, (4) } \\
\text { practitioners, (5) communities, (6) individuals, (7) thinking and } \\
\text { doing by researchers, (8) collaborative scientific innovation and } \\
\text { development as basis for change and (9) new local and global } \\
\text { paradigms into assessment, development of indicators and } \\
\text { collection of information }\end{array}$ \\
\hline $\begin{array}{l}\text { Framework that is (1) comprehensive, (2) understandable to the } \\
\text { society, (3) information-driven, (4) transparent, (5) covers the } \\
\text { whole process (monitor, assess, learn, decide and act) and (6) }\end{array}$ & $\begin{array}{l}\text { Integration of social sustainability indicator framework that is } \\
\text { (1) comprehensive, (2) understandable to the society, (3) } \\
\text { information-driven, (4) transparent, (5) covers the whole } \\
\text { process (monitor, assess, learn, decide and act) and (6) supports } \\
\text { decision making by people into assessment, development of } \\
\text { indicators and collection of information }\end{array}$ \\
\hline
\end{tabular}


Table 11. Cont.

Sustainability Indicator Development Focus Areas

(1) Earth observation data need to be used to support the development and diversity of SDGs indicators [146], (2) selection, revision and refinement based on the appropriate communities of interest [134] and (3) wider application of knowledge about indicators to specific management situations [58]

(1) Social norms (reflect sustainability principles and goals), (2) sustainability indicators (to provide clear information for decision making and steering of policies) and (3) a good narrative (making the complex sustainable development concept comprehensible to all) are among the missing enabling conditions for sustainable development $[59,147]$

(1) Society needs relevant indicators to make the right decisions about and to build public support for sustainable development [147] and (2) it is essential to conceptualize and operationalize the targets of the SDGs with particular emphasis on the relevance of indicators [148]

(1) Sustainability index development based on ethics (e.g., justice and equity) to ensure alignment with sustainability ethics and (2) research on how sustainability indexes address participatory and distributive intra- and intergenerational justice taking into account the challenges related to insufficient data [149]

(1) Monitoring to support development, use and inclusion of future scenarios [139], (2) inclusion of the notions of people about sustainability in the development and application [150] and (3) support of sustainable development based on an indicator system as an essential platform taking into account all views, issues, actions and diversities [48]

New sustainability index development methods and indexes to ensure that (1) indexes encourage and monitor participatory justice (the ability of people to participate in decision making and to meaningfully contribute to decisions affecting their lives) and distributive justice (equitable distribution of environmental benefits and burdens) between present and future generations and among currently living people and (2) indicators and indexes are in accordance with both normative and technical aspects of sustainability [149]

(1) Complementation of a global set of individual indicators by a set of key indicators considering that many complementary indicators and data sets are likely to emerge for national and regional SDGs assessment [151] and (2) value-based sustainability indicators and assessment tools to address ethical values [152]

(1) Case studies on development and use, (2) top-down vs. bottom-up approaches, (3) aggregation of indicators, (4) data provision, (5) a systems perspective and (6) alternatives to Gross Domestic Product [153]
Social Sustainability Handprint Assessment Approaches

Integration of (1) earth observation data to support the development and diversity of SDGs indicators, (2) selection, revision and refinement of indicators based on the appropriate communities of interest and (3) wider application of knowledge about indicators to specific management situations into assessment, development of indicators and collection of information

Integration of (1) social norms (sustainability principles and goals), (2) sustainability indicators (to provide clear information for decision making and steering of policies) and (3) a good narrative (making sustainable development comprehensible to all) into assessment, development of indicators and collection of information

Integration of (1) relevant indicators to make the right decisions about and to build public support for sustainable development and (2) the conceptualization and operationalization of the targets of the SDGs (with particular emphasis on the relevance of indicators) into assessment, development of indicators and collection of information

Integration of (1) sustainability index development based on ethics (e.g., justice and equity), (2) alignment with sustainability ethics, (2) participatory and distributive intra- and intergenerational and (3) sufficient and high-quality information and data into assessment, development of indicators and collection of information

Integration of (1) monitoring to support development, use and inclusion of future scenarios, (2) the notions of people about sustainability, (3) the promotion of sustainable development, (4) an indicator system (platform) and (5) all views, issues, actions and diversities into assessment, development of indicators and collection of information

Integration of (1) new sustainability index development and indices, (2) the ability of people to participate in decision making, (3) meaningful contributions of people to decisions affecting their lives, (4) equitable distribution of environmental benefits and burdens, (5) participatory justice and distributive justice between present and future generations and among currently living people and (6) indicators and indices that are in accordance with both normative and technical aspects of sustainability into assessment, development of indicators and collection of information

Integration of (1) a global set of individual indicators, (2) a set of key indicators, (3) many indicators and data sets based on national and regional SDGs assessments, (4) value-based sustainability indicators and assessment approaches and (5) ethical values into assessment, development of indicators and collection of information

Integration of (1) case studies on development and use, (2) top-down vs. bottom-up approaches, (3) aggregation of indicators, (4) data provision, (5) a systems perspective and (6) social and societal sustainability, well-being and quality of life-oriented alternatives to Gross Domestic Product into assessment, development of indicators and collection of information 
Table 11. Cont.

Sustainability Indicator Development Focus Areas

(1) The development and use of sustainability indices (case studies and linking use information to development and presentation), (2) more systemic perspective and integrated approach to goals and targets (alternatives to linear thinking), (3) top-down versus bottom-up (particular context, open discussion, participation and continuous exploration), (4) aggregation of indicators (e.g., more focus on users), (5) data provision (good quality and timely data) and (6) alternatives to Gross Domestic Product and economic-based indicators [137]
Social Sustainability Handprint Assessment Approaches

Integration of (1) the development and use of sustainability indices based on case studies and linking of use information to development, (2) systemic perspectives and integrated approaches to goals and targets as alternatives to linear thinking (e.g., in the context of circular economy), (3) top-down vs. bottom-up approaches, (4) particular contexts, (5) open discussion and participation, (6) continuous exploration, (7) aggregation of indicators with focus on users, (8) the provisions of good quality and timely information and data and (9) alternatives to Gross Domestic Product that are oriented towards social and societal sustainability, well-being and quality of life (including sustainable social/society-environment relationships and interfaces) into assessment, development of indicators and collection of information

\section{Conclusions}

The findings of this study suggest that social sustainability handprints provide significant potential to advance both social and societal sustainability based on the overall frameworks of both sustainable development and sustainability including the promotion of more sustainable social/society-environment relationships and interfaces. Social sustainability handprints can be created through multiple actions, changes, innovations and impacts to promote social sustainability based on sustainable development, sustainability and social and societal sustainability. Various actors such as all types of organizations, individuals, groups and companies can implement these ways to create social sustainability handprints. In addition, there are multiple assessment approaches that can be applied to the assessment of social sustainability handprints such as sustainability management, assessment and indicators, sustainability science and handprint and life cycle thinking and approaches. All these approaches contribute to improved social sustainability management based on social sustainability assessment and can be applied by all types of organizations.

In brief, the studied frameworks provide numerous ways to create and approaches to assess social sustainability handprints that can be used and further developed by multiple actors such as all types of organizations. Future research should focus on further theoretical and practical development of the creation of social sustainability handprints in the contexts of sustainable development, sustainability and social and societal sustainability. In addition, future studies need to pay similar attention to the development of the assessment of social sustainability handprints in the contexts of sustainability assessment and sustainability indicators. This theoretical and practical development needs to address all ways to create social sustainability handprints such as changes, actions, innovations and impacts and all assessment approaches such as sustainability science, sustainability management, assessment and indicators and handprint and life cycle thinking and approaches. Transdisciplinary approaches and real-life case studies based on continuous social and societal learning are highly recommended for this kind of future research and development.

Funding: This research was funded by the Kone Foundation, 202006340.

Acknowledgments: This study was supported by the Kone Foundation and this support made it possible to carry out this study.

Conflicts of Interest: The author declares no conflict of interest. The funder had no role in the design of the study; in the collection, analyses, or interpretation of data; in the writing of the manuscript, or in the decision to publish the results. 


\section{References}

1. The Ahmedabad Declaration 2007: A Call to Action. Education for life: Life Through Education, 28th November 2007. Available online: http:/ / www.unevoc.net/fileadmin/user_upload/docs/AhmedabadDeclaration.pdf (accessed on 15 March 2021).

2. About Handprint. Available online: www.handprint.in/ (accessed on 12 March 2021).

3. Biemer, J.R. Our Environmental Handprint: Recover the Land, Reverse Global Warming, Reclaim the Future; Rowman \& Littlefield: Lanham, MD, USA, 2021; ISBN 1538140659.

4. The Handprint Idea. Handprint-Action Towards Sustainability. Center for Environment Education. Available online: www. handprint.in/the_handprint_idea (accessed on 9 December 2020).

5. Vatanen, S.; Grönman, K.; Pajula, T.; Pihkola, H.; Soukka, R.; Kasurinen, H.; Behm, K.; Hohenthal, C.; Sillman, J.; Leino, M. The Carbon Handprint Approach to Assessing and Communicating the Positive Climate Impact of Products; VTT Technical Research Centre of Finland: Espoo, Finland, 2018.

6. SHINE Summit. Innovating for NetPositive Impact. Summary Report. 2015. Sustainability and Health Initiative for NetPositive Enterprise (SHINE); Center for Health and the Global Environment. Harvard, T.H. Chan School of Public Health: Boston, MA, USA, 2015.

7. Norris, G.; Burek, J.; Moore, E.A.; Kirchain, R.E.; Gregory, J. Sustainability health initiative for NetPositive Enterprise handprint methodological framework. Int. J. Life Cycle Assess. 2021, 26, 528-542. [CrossRef]

8. Guillaume, J.H.A.; Sojamo, S.; Porkka, M.; Gerten, D.; Jalava, M.; Lankoski, L.; Lehikoinen, E.; Lettenmeier, M.; Pfister, S.; Usva, K.; et al. Giving legs to handprint thinking: Foundations for evaluating the good we do. Earth Future 2020, 8, e2019EF001422. [CrossRef]

9. Pandya, M.; Vyas, P.; Schwarz, R. From Footprint to Handprint. Our Personal Action for Sustainable Development. Centre for Environment Education. Available online: http:/ / www.handprint.in/pdf/Handprint\%20article\%20GEER\%20final.pdf (accessed on 23 March 2021).

10. Biemer, J. Environmental Educators Create Handprints. Environmental Handprints, Conservation \& Sustainability, Outstanding Programs in EE, Clearing, Supporting Environmental Literacy Education in the Pacific Northwest and Cascadia Bioregion. 2018. Available online: https:/ / clearingmagazine.org/archives/13601 (accessed on 23 March 2021).

11. Biemer, J.; Dixon, W.; Blackburn, N. Our environmental handprint. The good we do. In Proceedings of the 20131 st IEEE Conference on Technologies for Sustainability (SusTech), Institute of Electrical and Electronic Engineers, Portland, OR, USA, 1-2 August 2013; pp. 146-153.

12. Germanwatch. A tool for More Sustainability. Available online: germanwatch.org/de/17687 (accessed on 19 March 2021).

13. Germanwatch. Climate Action: Decrease your Footprint and Increase your Handprint. Education for Sustainable Development. 2015. Available online: germanwatch.org/sites/default/ files/publication/13638.pdf (accessed on 23 March 2021).

14. WCED 1987. Report of the World Commission on Environment and Development. Available online: sustainabledevelopment.un. org/content/documents/5987our-common-future.pdf (accessed on 13 August 2021).

15. Kates, R.W.; Parris, T.M. Long-term trends and a sustainability transition. Proc. Natl. Acad. Sci. USA 2003, 100, 8062-8067. [CrossRef]

16. Waas, T.; Hugé, J.; Block, T.; Wright, T.; Benitez-Capistros, F.; Verbruggen, A. Sustainability assessment and indicators: Tools in a decision-making strategy for sustainable development. Sustainability 2014, 6, 5512-5534. [CrossRef]

17. Bell, S.; Morse, S. Measuring Sustainability, 1st ed.; Routledge: New York, NY, USA, 2013; ISBN 9781853838439.

18. De Vries, B.J.; Petersen, A.C. Conceptualizing sustainable development: An assessment methodology connecting values, knowledge, worldviews and scenarios. Ecol. Econ. 2009, 68, 1006-1019. [CrossRef]

19. Peattie, K. Developing and delivering social science research for sustainability. In Researching Sustainability. A Guide to Social Science Methods, Practice and Engagement; Franklin, A., Blyton, P., Eds.; Taylor \& Francis Group: London, UK, 2011 ; pp. 17-33. ISBN 1849711216.

20. Waas, T.; Hugé, J.; Verbruggen, A.; Wright, T. Sustainable development: A Bird's eye view. Sustainability 2011, 3, $1637-1661$. [CrossRef]

21. Talan, A.; Pathak, A.N.; Tyagi, R.D. The need, role and significance of sustainability. In Sustainability. Fundamentals and Applications; Surampalli, R.Y., Zhang, T.C., Goyal, M.K., Brar, S.K., Tyagi, R.D., Eds.; John Wiley \& Sons Incorporated: Hoboken, NJ, USA, 2020; pp. 21-41. ISBN 1119433967.

22. Raskin, P.D.; Electris, C.; Rosen, R.A. The century ahead: Searching for sustainability. Sustainability 2010, 2, 2626-2651. [CrossRef]

23. Martínez-Blanco, J.; Lehmann, A.; Muñoz, P.; Antón, A.; Traverso, M.; Rieradevall, J.; Finkbeiner, M. Application challenges for the social LCA of fertilizers within life cycle sustainability assessment. J. Clean. Prod. 2014, 69, 34-48. [CrossRef]

24. Grönman, K.; Pajula, T.; Sillman, J.; Leino, M.; Vatanen, S.; Kasurinen, H.; Soininen, A.; Soukka, R. Carbon handprint-An approach to assess the positive climate impacts of products demonstrated via renewable diesel case. J. Clean. Prod. 2019, 206, 1059-1072. [CrossRef]

25. Kühnen, M.; Silva, S.; Beckman, J.B.; Eberle, U.; Hahn, R.; Hermann, C.; Shaltegger, S.; Schmid, M. Contributions to the sustainable development goals in life cycle sustainability assessment: Insights from the handprint research project. Sustain. Manag. Forum 2019, 27, 65-82. [CrossRef]

26. Behm, K.; Husgafvel, R.; Hohenthal, C.; Pihkola, H.; Vatanen, S. Carbon Handprint-Communicating the good we do. Research Report, VTT, 29 p. Available online: http:/ / www.sitra.fi/julkaisu/2016/carbon-handprint (accessed on 26 March 2021). 
27. Troullaki, K.; Rozakis, S.; Kostakis, V. Bridging barriers in sustainability research: A review from sustainability science to life cycle sustainability assessment. Ecol. Econ. 2021, 184, 107007. [CrossRef]

28. Lehmann, A.; Russi, D.; Bala, A.; Finkbeiner, M.; Fullana-i-Palmer, P. Integration of social aspects in decision support, based on life cycle thinking. Sustainability 2011, 3, 562-577. [CrossRef]

29. Schaubroeck, T.; Benedetto, R. A revision of what life cycle sustainability assessment should entail: Towards modeling the net impact on human well-being: A revision of life cycle sustainability assessment. J. Ind. Ecol. 2017, 21, 1464-1477. [CrossRef]

30. Finkbeiner, M.; Schau, E.M.; Lehmann, A.; Traverso, M. Towards life cycle sustainability assessment. Sustainability 2010, 2, 3309-3322. [CrossRef]

31. Kolsch, D.; Saling, P.; Kicherer, A.; Grosse-Sommer, A.; Schmidt, I. How to measure social impacts? A socio-eco-efficiency analysis by the SEEBALANCE ${ }^{\circledR}$ method. Int. J. Sustain. Dev. 2008, 11, 1-23. [CrossRef]

32. Husgafvel, R. Exploring social sustainability handprint-Part 1: Handprint and life cycle thinking and approaches. Sustainability 2021. accepted.

33. Husgafvel, R. Exploring sustainability science, Agenda 2030 and the UN SDGs from the social sustainability handprint perspective. In Handbook of Sustainability Science in the Future; Springer: Berlin/Heidelberg, Germany, 2021; accepted.

34. Saldana, J. Fundamentals of Qualitative Research; Oxford University Press: Oxford, UK, 2011; pp. 3-30. ISBN 0199737959.

35. Husgafvel, R.; Poikela, K.; Honkatukia, J.; Dahl, O. Development and piloting of sustainability assessment metrics for arctic process industry in Finland-The biorefinery investment and slag processing service cases. Sustainability 2017, 9, 1693. [CrossRef]

36. Husgafvel, R.; Pajunen, N.; Virtanen, K.; Paavola, I.-L.; Päällysaho, M.; Inkinen, V.; Heiskanen, K.; Dahl, O.; Ekroos, A. Social sustainability performance indicators-Experiences from process industry. Int. J. Sustain. Eng. 2014, 8, 14-25. [CrossRef]

37. Husgafvel, R.; Pajunen, N.; Päällysaho, M.; Paavola, I.-L.; Inkinen, V.; Heiskanen, K.; Dahl, O.; Ekroos, A. Social metrics in the process industry-Background, theory and development work. Int. J. Sustain. Eng. 2013, 7, 171-182. [CrossRef]

38. Cordonier Segger, M.-C.; Khalfan, A. Sustainable Development Law: Principles, Practices and Prospects; Oxford University Press: Oxford, UK, 2004; ISBN 0199276714.

39. Kates, R.W.; Parris, T.M.; Leiserowitz, A.A. What is sustainable development? Goals, indicators, values and practice. Environ. Sci. Policy Sustain. Dev. 2005, 47, 8-21. [CrossRef]

40. De Vries, B.J.M. Sustainability Science; Cambridge University Press: Cambridge, MA, USA, 2012; ISBN 0521184703.

41. Clark, W.C.; Harley, A.G. Sustainability Science: Toward a Synthesis. Annu. Rev. Environ. Resour. 2020, 45, 331-386. [CrossRef]

42. Diwekar, U.; Amekudzi-Kennedy, A.; Bakshi, B.; Baumgartner, R.; Boumans, R.; Burger, P.; Cabezas, H.; Egler, M.; Farley, J.; Fath, B.; et al. A perspective on the role of uncertainty in sustainability science and engineering. Perspective. Resour. Conserv. Recycl. 2021, 164, 105140. [CrossRef] [PubMed]

43. Schrijver, N.J. Evolution of Sustainable Development in International Law: Inception, Meaning and Status; Hague Academy of International Law: Hague, The Netherlands, 2008; pp. 162-207. ISBN 9004174079.

44. Cordonier Segger, M.-C. Significant developments in sustainable development law and governance: A proposal. Nat. Resour. Forum 2004, 28, 61-74. [CrossRef]

45. ILA New Delhi Declaration of Principles of International Law Relating to Sustainable Development. A/57/329. General Assembly. The United Nations. Available online: undocs:pdf?symbol=en/A/57/329 (accessed on 17 August 2021).

46. Summary of Proposed Legal Principles for Environmental Protection and Sustainable Development Adopted by the WCED Expert Group on Environmental Law. Annex 1. Report of the World Commission on Environment and Development. Available online: sustainabledevelopment.un:content/documents/5987our-common-future.pdf (accessed on 18 August 2021).

47. Kates, R.W. Readings in Sustainability Science and Technology; CID Working Paper No. 213; Center for International Development, Harvard University: Cambridge, MA, USA, 2010.

48. Sharma, P.; Singh., K. Sustainable development: Dimensions, intersections and knowledge platform. In Sustainability. Fundamentals and Applications; Surampalli, R.Y., Zhang, T.C., Goyal, M.K., Brar, S.K., Tyagi, R.D., Eds.; John Wiley \& Sons: Hoboken, NJ, USA, 2020; pp. 43-68. ISBN 1119433967.

49. Rout, P.R.; Verma, A.K.; Bhunia, P.; Surampalli, R.Y.; Zhang, T.C.; Tyagi, R.D.; Brar, S.K.; Goyal, M.K. Introduction to sustainability and sustainable development. In Sustainability. Fundamentals and Applications; Surampalli, R.Y., Zhang, T.C., Goyal, M.K., Brar, S.K., Tyagi, R.D., Eds.; John Wiley \& Sons: Hoboke, NJ, USA, 2020; pp. 3-19. ISBN 1119433967.

50. Wilson, J.; Tyedmers, P.; Pelot, R. Contrasting and comparing sustainable development indicator metrics. Ecol. Indic. 2007, 7, 299-314. [CrossRef]

51. Stafford-Smith, M.; Griggs, D.; Gaffney, O.; Ullah, F.; Reyers, B.; Kanie, N.; Stigson, B.; Shrivastava, P.; Leach, M.; O’Connell, D. Integration: The key to implementing the sustainable development goals. Sustain. Sci. 2017, 12, 911-919. [CrossRef]

52. Gibson, R.B. Sustainability assessment: Basic components of a practical approach. Impact Assess. Proj. Apprais. 2006, $24,170-182$. [CrossRef]

53. Moldan, B.; Dahl, A.L. Challenges to Sustainability Indicators. In Sustainability Indicators: A Scientific Assessment, Scientific Committee on Problems of the Environment (SCOPE) Series; Hák, T., Moldan, B., Dahl, A.L., Eds.; Island Press: Washington, DC, USA, 2007; pp. 1-24. ISBN 1597261319.

54. Martens, P. Sustainability: Science or fiction? Sustain. Sci. Pract. Policy 2006, 2, 36-41. [CrossRef]

55. Schrijver, N.J. Evolution of Sustainable Development in International Law: Inception, Meaning and Status; Hague Academy of International Law: Hague, The Netherlands, 2008; pp. 23-32. ISBN 9004174079. 
56. Schrijver, N.J. Evolution of Sustainable Development in International Law: Inception, Meaning and Status; Hague Academy of International Law: Hague, The Netherlands, 2008; pp. 102-161. ISBN 9004174079.

57. Schrijver, N.J. Evolution of Sustainable Development in International Law: Inception, Meaning and Status; Hague Academy of International Law: Hague, The Netherlands, 2008; pp. 208-230. ISBN 9004174079.

58. National Research Council. Our Common Journey: A Transition Toward Sustainability; The National Academies Press: Washington, DC, USA, 1999. [CrossRef]

59. Janoušková, S.; Hák, T.; Nečas, V.; Moldan, B. Sustainable development-A poorly communicated concept by mass media. another challenge for SDGs? Sustainability 2019, 11, 3181. [CrossRef]

60. Stumpf, K.H.; Baumgärtner, S.; Becker, C.U.; Sievers-Glotzbach, S. The justice dimension of sustainability: A systematic and general conceptual framework. Sustainability 2015, 7, 7438-7472. [CrossRef]

61. Gibson, R.B. Beyond the pillars: Sustainability assessment as a framework for effective integration of social, economic and ecological considerations in significant decision-making. J. Environ. Assess. Policy Manag. 2006, 8, 259-280. [CrossRef]

62. Third Symposium on Sustainability Science: Towards Guidelines on Research and Education. UNESCO Headquarters-Room XIII (Bonvin Building) 31 May-1 June 2017. Report. Natural Sciences Sector. Social and Human Sciences Sector. United Nations Educational, Scientific and Cultural Organization. Available online: en.unesco:sites/default/files/sus_3_report.pdf (accessed on 18 August 2021).

63. Shrivastava, P.; Smith, M.S.; O'Brien, K.; Zsolnai, L. Transforming sustainability science to generate positive social and environmental change globally. perspective. One Earth 2020, 2, 329-340. [CrossRef] [PubMed]

64. Parris, T.M.; Kates, R.W. Characterizing a sustainability transition: Goals, targets, trends, and driving forces. Proc. Natl. Acad. Sci. USA 2003, 100, 8068-8073. [CrossRef] [PubMed]

65. Portney, K.E. Sustainability; The MIT Press: Cambridge, MA, USA, 2015; ISBN 9780262528504.

66. König, A. Systems approaches for transforming social practice. Design requirements. In Sustainability Science: Key Issues; König, A., Ed.; Routledge: London, UK; New York, NY, USA, 2018; pp. 55-81. ISBN 1138659282.

67. Carpenter, S. Measuring and Monitoring Progress Towards Sustainability. Background Paper for Conference on Towards a Science of Sustainability. In Report from Toward a Science of Sustainability Conference, Airlie Center, Warrenton, Virginia, USA, November 29, 2009-December 2, 2009, pp. 129-133. Available online: http://www.nsf.gov/mps/dms/documents/ SustainabilityWorkshopReport.pdf (accessed on 18 August 2021).

68. Leiserowitz, A.A.; Kates, R.W.; Parris, T.M. Sustainability values, attitudes, and behaviors: A review of multinational and global trends. Annu. Rev. Environ. Resour. 2006, 31, 413-444. [CrossRef]

69. Faber, N.; Jorna, R.; van Engelen, J. The sustainability of "Sustainability"-A study into the conceptual foundations of the notion of "Sustainability". J. Environ. Assess. Policy Manag. 2005, 7, 1-33. [CrossRef]

70. Peterson, N. Introduction to the special issue on social sustainability: Integration, context, and governance. Sustain. Sci. Pract. Policy 2016, 12, 3-7. [CrossRef]

71. Dahl, A.L. Achievements and gaps in indicators for sustainability. Ecol. Indic. 2012, 17, 14-19. [CrossRef]

72. Gibson, R.B.; Hassan, S.; Holtz, S.; Tansey., J.; Whitelaw, G. Sustainability Assessment: Criteria and Processes; Taylor \& Francis Group: London, UK, 2005; ISBN 1844070514.

73. Guidelines on Sustainability Science in Research and Education. Natural Sciences Sector. Social and Human Sciences Sector. United Nations Educational, Scientific and Cultural Organization. Available online: en.unesco:sites/default/files/guidelines_ sus_f_0.pdf (accessed on 19 August 2021).

74. Oosterbeek, L. Outcomes of discussion on key principles of sustainability science. Presentation. Third Symposium on Sustainability Science: Towards Guidelines on Research and Education. UNESCO Headquarters-Room XIII (Bonvin Building) 31 May -1 June 2017. Natural Sciences Sector. Social and Human Sciences Sector. United Nations Educational, Scientific and Cultural Organization, 2017. Available online: en.unesco:sites/default/files/panel_1_presentation_luizoosterbeek.pdf (accessed on 19 August 2021).

75. Denis, M. Mainstreaming Sustainability Science in Research. Presentation. Third Symposium on Sustainability Science: Towards Guidelines on Research and Education. UNESCO Headquarters-Room XIII (Bonvin Building) 31 May-1 June 2017. Natural Sciences Sector. Social and Human Sciences Sector. United Nations Educational, Scientific and Cultural Organization, 2017. Available online: en.unesco:sites/default/files/panel_4_presentation_mathieudenis.pdf (accessed on 19 August 2021).

76. Takeuchi, K. Role of Research in Sustainability Science for Implementing the SDGs. Presentation. Third Symposium on Sustainability Science: Towards Guidelines on Research and Education. UNESCO Headquarters-Room XIII (Bonvin Building) 31 May -1 June 2017. Natural Sciences Sector. Social and Human Sciences Sector. United Nations Educational, Scientific and Cultural Organization, 2017. Available online: en.unesco:sites/default/files/panel_4_presentation_kazuhikotakeuchi.pdf (accessed on 19 August 2021).

77. Keitsch, M. Structuring ethical interpretations of the sustainable development goals—Concepts, implications and progress. Sustainability 2018, 10, 829. [CrossRef]

78. Chiu, A.S.F.; Aviso, K.B.; Tan, R.R. Differentiating ethical imperatives of the collective sustainability research community and the individual researcher. Correspondence. Resour. Conserv. Recycl. 2020, 160, 104928. [CrossRef]

79. Weinstein, M.P.; Turner, R.E. (Eds.) Preface. In Sustainability Science. The Emerging Paradigm and the Urban Environment; Springer: New York, NY, USA, 2012; pp. 7-12. [CrossRef] 
80. Van Mierlo, B.; Halbe, J.; Beers, P.J.; Scholz, G.; Vinke-de Kruijf, J. Learning about learning in sustainability transitions. Environ. Innov. Soc. Transit. 2020, 34, 251-254. [CrossRef]

81. Goyal, N.; Howlett, M. Who learns what in sustainability transitions? Environ. Innov. Soc. Transit. 2020, 34, 311-321. [CrossRef]

82. Patterson, J.; Schulz, K.; Vervoort, J.; van der Hel, S.; Widerberg, O.; Adler, C.; Hurlbert, M.; Anderton, K.; Sethi, M.; Barau, A. Exploring the governance and politics of transformations towards sustainability. Environ. Innov. Soc. Transit. 2017, 24, 1-16. [CrossRef]

83. Van Mierlo, B.; Beers, P.J. Understanding and governing learning in sustainability transitions: A review. Environ. Innov. Soc. Transit. 2020, 34, 255-269. [CrossRef]

84. Van Poeck, K.; Östman, L.; Block, T. Opening up the black box of learning-by-doing. Environ. Innov. Soc. Transit. 2020, 34, 298-310. [CrossRef]

85. Shiroyama, H.; Yarime, M.; Matsuo, M.; Schroeder, H.; Scholz, R.; Ulrich, A.E. Governance for sustainability: Knowledge integration and multi-actor dimensions in risk management. Sustain. Sci. 2012, 7, 45-55. [CrossRef]

86. Brandt, P.; Ernst, A.; Gralla, F.; Luederitz, C.; Lang, D.J.; Newig, J.; Reinert, F.; Abson, D.J.; von Wehrden, H. A review of transdisciplinary research in sustainability science. Ecol. Econ. 2013, 92, 1-15. [CrossRef]

87. Cash, D.W.; Clark, W.C.; Alcock, F.; Dickson, N.M.; Eckley, N.; Guston, D.H.; Jäger, J.; Mitchell, R.B. Knowledge systems for sustainable development. Proc. Natl. Acad. Sci. USA. 2003, 100, 8086-8091. [CrossRef]

88. Devuyst, D. Linking impact assessment and sustainable development at the local level: The introduction of sustainability assessment systems. Sustain. Dev. 2000, 8, 67-78. [CrossRef]

89. Miller, T.R.; Wiek, A.; Sarewitz, D.; Robinson, J.; Olsson, L.; Kriebel, D.; Loorbach, D. The future of sustainability science: A solutions-oriented research agenda. Sustain. Sci. 2014, 9, 239-246. [CrossRef]

90. Jerneck, A.; Olsson, L.; Ness, B.; Anderberg, S.; Baier, M.; Clark, E.; Hickler, T.; Hornborg, A.; Kronsell, A.; Lövbrand, E.; et al. Structuring sustainability science. Sustain. Sci. 2011, 6, 69-82. [CrossRef]

91. Salas, Z.W.A.; Ortiz, M.S.M. Analysis of meanings of the concept of sustainability. Sustain. Dev. 2019, 27, 153-161. [CrossRef]

92. Vallance, S.; Perkins, H.C.; Dixon, J.E. What is social sustainability? A clarification of concepts. Geoforum 2011, 42, 342-348. [CrossRef]

93. Colantonio, A.; Dixon, T. (Eds.) Social sustainability and sustainable communities: Towards a conceptual framework. In Urban Regeneration and Social Sustainability: Best Practice from European Cities; John Wiley \& Sons: Hoboken, NJ, USA, 2010 ; pp. 18-36.

94. Littig, B.; Grießler, E. Social sustainability: A catchword between political pragmatism and social theory. Int. J. Sustain. Dev. 2005, 8, 65-79. [CrossRef]

95. Magis, K.; Shinn, C. Emergent principles of social sustainability. In Understanding the Social Dimension of Sustainability; Dillard, J., Dujon, V., King, M.C., Eds.; Routledge: New York, NY, USA; London, UK, 2009; pp. 15-44. ISBN 0415964652.

96. Dillard, J.; Dujon, V.; King, M.C. (Eds.) Reflection and directions for the future. In Understanding the Social Dimension of Sustainability; Routledge: New York, NY, USA; London, UK, 2009; pp. 285-290. ISBN 0415964652.

97. Colantonio, A.; Dixon, T. Metrics and tools for social sustainability. In Urban Regeneration and Social Sustainability: Best Practice from European Cities; Colantonio, A., Dixon, T., Eds.; John Wiley \& Sons: Hoboken, NJ, USA, 2010; pp. 37-53. [CrossRef]

98. McKenzie, S. Social Sustainability: Towards some Definitions; Working Paper Series No. 27; Hawke Research Institute: Nijmegen, The Netherlands, 2004.

99. Cuthill, M. Strengthening the 'social' in sustainable development: Developing a conceptual framework for social sustainability in a rapid urban growth region in Australia. Sustain. Dev. 2010, 18, 362-373. [CrossRef]

100. Colantonio, A. Social sustainability: A review and critique of traditional versus emerging themes and assessment methods. In SUE-Mot Conference 2009: Second International Conference on Whole Life Urban Sustainability and its Assessment: Conference Proceedings; Horner, M., Price, A., Bebbington, J., Emmanuel, R., Eds.; Loughborough University: Loughborough, UK, 2009 ; pp. 865-885. ISBN 9780947974.

101. Colantonio, A.; Dixon, T. Conclusions. In Urban Regeneration and Social Sustainability: Best Practice from European Cities; Colantonio, A., Dixon, T., Eds.; John Wiley \& Sons: Hoboken, NJ, USA, 2010; pp. 240-258. [CrossRef]

102. Dempsey, N.; Bramley, G.; Power, S.; Brown, C. The Social Dimension of Sustainable Development: Defining Urban Social Sustainability. Sustain. Dev. 2011, 19, 289-300. [CrossRef]

103. Murphy, K. The social pillar of sustainable development: A literature review and framework for policy analysis. Sustain: Sci. Pract. Policy 2012, 8, 15-29. [CrossRef]

104. Dillard, J.; Dujon, V.; King, M.C. Introduction. In Understanding the Social Dimension of Sustainability; Dillard, J., Dujon, V., King, M.C., Eds.; Routledge: New York, NY, USA; London, UK, 2009; pp. 1-12. ISBN 0415964652.

105. Boström, M. A missing pillar? Challenges in theorizing and practicing social sustainability: Introduction to the special issue. Sustain. Sci. Pract. Policy 2012, 8, 3-14. [CrossRef]

106. Boyer, R.H.W.; Peterson, N.D.; Arora, P.; Caldwell, K. Five approaches to social sustainability and an integrated way forward. Sustainability 2016, 8. [CrossRef]

107. Talan, A.; Tyagi, R.D.; Surampalli, R.Y. Social dimensions of sustainability. In Sustainability. Fundamentals and Applications; Surampalli, R.Y., Zhang, T.C., Goyal, M.K., Brar, S.K., Tyagi, R.D., Eds.; John Wiley \& Sons: Hoboken, NJ, USA, 2020 ; pp. 183-206. ISBN 1119433967. 
108. Bebbington, J.; Dillard, J. Social sustainability. An organizational-level analysis. In Understanding the Social Dimension of Sustainability; Dillard, J., Dujon, V., King, M.C., Eds.; Routledge: New York, NY, USA; London, UK, 2009; pp. 157-173. ISBN 0415964652.

109. Dillard, J.; Layzell, D. Social sustainability. One company's story. In Understanding the Social Dimension of Sustainability; Dillard, J., Dujon, V., King, M.C., Eds.; Routledge: New York, NY, USA; London, UK, 2009; pp. 174-198. ISBN 0415964652.

110. Rogers, S.H.; Gardner, K.H.; Carlson, C.H. Social capital and walkability as social aspects of sustainability. Sustainability 2013, 5, 3473-3483. [CrossRef]

111. Kato, H. Problem-structuring methods based on a cognitive mapping approach. In Sustainability Science: A Multidisciplinary Approach; Komiyama, H., Takeuchi, K., Shiroyama, H., Mino, T., Eds.; United Nations University Press: Tokyo, Japan, 2011; pp. 122-144. ISBN 9280811800.

112. Onuki, M.; Mino, T. Key concepts for sustainability education. In Sustainability Science: A Multidisciplinary Approach; Komiyama, H., Takeuchi, K., Shiroyama, H., Mino, T., Eds.; United Nations University Press: Tokyo, Japan, 2011; pp. 385-389. ISBN 9280811800 .

113. Kurata, N. Public deliberation for sustainability governance: GMO debates in Hokkaido. In Sustainability Science: A Multidisciplinary Approach; Komiyama, H., Takeuchi, K., Shiroyama, H., Mino, T., Eds.; United Nations University Press: Tokyo, Japan, 2011; pp. 190-203. ISBN 9280811800.

114. Kajikawa, Y. The structuring of knowledge. In Sustainability Science: A Multidisciplinary Approach; Komiyama, H., Takeuchi, K., Shiroyama, H., Mino, T., Eds.; United Nations University Press: Tokyo, Japan, 2011; pp. 22-34. ISBN 9280811800.

115. Kajikawa, Y.; Komiyama, H. The structuring of action. In Sustainability Science: A Multidisciplinary Approach; Komiyama, H., Takeuchi, K., Shiroyama, H., Mino, T., Eds.; United Nations University Press: Tokyo, Japan, 2011; pp. 35-46. ISBN 9280811800.

116. Clark, W.C.; Harley, A.G. Sustainability Science: Towards a Synthesis; Sustainability Science Program Working Paper 2019-01; John F. Kennedy School of Government, Harvard University: Cambridge, MA, USA; Available online: http:/ / nrs.harvard.edu/urn-3: HUL.InstRepos:42574531 (accessed on 13 August 2021).

117. Verma, A.K.; Rout, P.R.; Lee, E.; Bhunia, P.; Bae, J.; Surampalli, R.Y.; Zhang, T.C.; Tyagi, R.D.; Lin, P.; Chen, Y. Biodiversity and sustainability. In Sustainability. Fundamentals and Applications; Surampalli, R.Y., Zhang, T.C., Goyal, M.K., Brar, S.K., Tyagi, R.D., Eds.; John Wiley \& Sons: Hoboken, NJ, USA, 2020; pp. 255-275. ISBN 1119433967.

118. Talan, A.; Kaur, R.; Tyagi, R.D.; Zhang, T.C. Ethical aspects of sustainability. In Sustainability. Fundamentals and Applications; Surampalli, R.Y., Zhang, T.C., Goyal, M.K., Brar, S.K., Tyagi, R.D., Eds.; John Wiley \& Sons: Hoboken, NJ, USA, 2020 ; pp. 397-411. ISBN 1119433967.

119. Pope, J.; Bond, A.; Hugé, J.; Morrison-Saunders, A. Reconceptualising sustainability assessment. Environ. Impact Assess. Rev. 2017, 62, 205-215. [CrossRef]

120. Pope, J. What's so special about sustainability management? J. Environ. Assess. Policy Manag. 2006, 8, v-x. [CrossRef]

121. Clark, W.C. Sustainable development and sustainability science. In Toward a Science of Sustainability; Report from Toward a Science of Sustainability Conference, Airlie Center, 29 November-2 December 2009, Warrenton, VA, USA; Levin, S.A., Clark, W.C. Eds.; 2009, pp. 80-100. Available online: http://www.nsf.gov/mps/dms/documents/SustainabilityWorkshopReport.pdf (accessed on 27 August 2021).

122. Dijk, M.; de Kraker, J.; van Zeijl-Rozema, A.; van Lente, H.; Beumer, C.; Beemsterboer, S.; Valkering, P. Sustainability assessment as problem structuring: Three typical ways. Sustain. Sci. 2017, 12, 305-317. [CrossRef]

123. Bond, A.; Morrison-Saunders, A.; Pope, J. Sustainability assessment: The state of the art. Impact Assess. Proj. Apprais. 2012, 30, 53-62. [CrossRef]

124. Sheate, W.R. (Ed.) The evolving nature of environmental assessment and management: Linking tools to help deliver sustainability. In Tools, Techniques and Approaches for Sustainability: Collected Writings in Environmental Assessment Policy and Management; World Scientific Publishing Company: Singapore, 2009; pp. 1-29. ISBN 981429117X.

125. Williams, S.; Robinson, J. Measuring sustainability: An evaluation framework for sustainability transition experiments. Environ. Sci. Policy 2020, 103, 58-66. [CrossRef]

126. Weaver, P.M.; Rotmans, J. Integrated sustainability assessment: What is it, why do it, and how? Int. J. Innov. Sustain. Dev. 2006, 1, 284-303. [CrossRef]

127. Cohen, M.A. Systematic review of urban sustainability assessment literature. Sustainability 2017, 9, 2048. [CrossRef]

128. Sala, S.; Ciuffo, B.; Nijkamp, P. A systemic framework for sustainability assessment. Ecol. Econ. 2015, 119, 314-325. [CrossRef]

129. Ramos, T.B. Sustainability assessment: Exploring the frontiers and paradigms of indicator approaches. Sustainability 2019, $11,824$. [CrossRef]

130. Gould, R.; Missimer, M.; Mesquita, P.L. Using social sustainability principles to analyse activities of the extraction lifecycle phase: Learnings from designing support for concept selection. J. Clean. Prod. 2017, 140, 267-276. [CrossRef]

131. Norman, L. Bridging the gap between theory and practice in integrated assessment. Environ. Impact Assess. Rev. 2006, 26, 57-78. [CrossRef]

132. Gasparatos, A.; El-Haram, M.; Horner, M. A critical review of reductionist approaches for assessing the progress towards sustainability. Environ. Impact Assess. Rev. 2008, 28, 286-311. [CrossRef] 
133. Axelsson, R.; Angelstam, P.; Degerman, E.; Teitelbaum, S.; Andersson, K.; Elbakidze, M.; Drotz, M.K. Social and cultural sustainability: Criteria, indicators, verifier variables for measurement and maps for visualization to support planning. Ambio 2013, 42, 215-228. [CrossRef] [PubMed]

134. Singh, R.K.; Murty, H.R.; Gupta, S.K.; Dikshit, A.K. An overview of sustainability assessment methodologies. Ecol. Indic. 2012, 15, 281-299. [CrossRef]

135. Morse, S. Developing sustainability indicators and indices. Sustain. Dev. 2015, 23, 84-95. [CrossRef]

136. Parris, T.M.; Kates, R.W. Characterizing and measuring sustainable development. Annu. Rev. Environ. Resour. 2003, $28,559-586$. [CrossRef]

137. Bell, S.; Morse, S. Sustainability indicators past and present: What next? Sustainability 2018, 10, 1688. [CrossRef]

138. Moldan, B.; Stewart, J.W.B.; Plocq-Fichelet, V. Sustainability Indicators: A Scientific Assessment; Scientific Committee on Problems of the Environment (SCOPE) Series; Hák, T., Moldan, B., Dahl, A.L., Eds.; Island Press: Washington, DC, USA, 2007; pp. xxiii-xxv. ISBN 1597261319.

139. Latawiec, A.E.; Agol, D. Conclusions—Sustainability indicators in practice: Lessons learned from the past, directions for the future. In Sustainability Indicators in Practice; Latawiec, A.E., Agol, D., Eds.; De Gruyter Open Poland: Warsaw, Poland, 2015; pp. 244-246. [CrossRef]

140. Garrett, R.; Latawiec, A.E. What are sustainability indicators for? Sustainability Indicators in Practice; De Gruyter Open: Warsaw, Poland, 2015; pp. 12-22. [CrossRef]

141. Haider, L.J.; Iribarrem, A.; Gardner, T.; Latawiec, A.E.; Alves-Pinto, H.; Strassburg, B. Understanding indicators and monitoring for sustainability in the context of complex social-ecological systems. In Sustainability Indicators in Practice; Latawiec, A.E., Agol, D., Eds.; De Gruyter Open Poland: Warsaw, Poland, 2015; pp. 23-36. [CrossRef]

142. Latawiec, A.E.; Agol, D. Introduction-Why sustainability indicators in practice? In Sustainability Indicators in Practice; Latawiec, A.E., Agol, D., Eds.; De Gruyter Open Poland: Warsaw, Poland, 2015; pp. 1-11. [CrossRef]

143. Robèrt, K.-H. Tools and concepts for sustainable development, how do they relate to a general framework for sustainable development, and to each other? J. Clean. Prod. 2000, 8, 243-254. [CrossRef]

144. Robèrt, K.-H.; Schmidt-Bleek, B.; Aloisi de Larderel, J.; Basile, G.; Jansen, J.L.; Kuehr, R.; Price Thomas, P.; Suzuki, M.; Hawken, P.; Wackernagel, M. Strategic sustainable development-Selection, design and synergies of applied tools. J. Clean. Prod. 2002, 10, 197-214. [CrossRef]

145. McGlade, J. Foreword: Finding the right indicators for policymaking. In Sustainability Indicators: A Scientific Assessment; Scientific Committee on Problems of the Environment (SCOPE) Series; Hák, T., Moldan, B., Dahl, A.L., Eds.; Island Press: Washington, DC, USA, 2007; pp. xvii-xxi. ISBN 1597261319.

146. Andries, A.; Morse, S.; Murphy, R.; Lynch, J.; Woolliams, E.; Fonweban, J. Translation of Earth observation data into sustainable development indicators: An analytical framework. Sustain. Dev. 2018, 27, 366-376. [CrossRef]

147. Hák, T.; Janouškováa, S.; Moldana, B.; Dahl, A.L. Closing the sustainability gap 30 years after "Our Common Future”, society lacks meaningful stories and relevant indicators to make the right decisions and build public support. Ecol. Indic. 2018, 87, 193-195. [CrossRef]

148. Hák, T.; Janoušková, S.; Moldan, B. Sustainable development goals: A need for relevant indicators. Ecol. Indic. 2016, 60, 565-573. [CrossRef]

149. Fredericks, S.E. Justice in sustainability indicators and indexes. Int. J. Sustain. Dev. World Ecol. 2012, 19, 490-499. [CrossRef]

150. Tasaki, T.; Kameyama, Y. Sustainability indicators: Are we measuring what we ought to measure? Glob. Environ. Res. 2015, 19, 147-154.

151. Janoušková, S.; Hák, T.; Moldan, B. Global SDGs assessments: Helping or confusing indicators? Sustainability 2018, $10,1540$. [CrossRef]

152. Burford, G.; Hoover, E.; Velasco, I.; Janoušková, S.; Jimenez, A.; Piggot, G.; Podger, D.; Harder, M.K. Bringing the "Missing Pillar" into sustainable development goals: Towards intersubjective values-based indicators. Sustainability 2013, 5, 3035-3059. [CrossRef]

153. Bell, S.; Morse, S. (Eds.) What next? In Routledge Handbook of Sustainability Indicators; Routledge: London, UK; New York, NY, USA, 2018; pp. 543-555. ISBN 1138674761. 